\title{
Molecular phylogeny and missense mutations of envelope proteins across coronaviruses
}

\author{
Sk. Sarif Hassan ${ }^{\mathrm{a}, *}$, Pabitra Pal Choudhury ${ }^{\mathrm{b}}$, Bidyut Roy $^{\mathrm{c}}$ \\ ${ }^{a}$ Department of Mathematics, Pingla Thana Mahavidyalaya, Maligram, Paschim Medinipur, 721140, West Bengal, India \\ ${ }^{b}$ Applied Statistics Unit, Indian Statistical Institute, Kolkata 700108, West Bengal, India \\ ${ }^{c}$ Human Genetics Unit, Indian Statistical Institute, Kolkata 700108, West Bengal, India
}

\begin{abstract}
Envelope protein is one of the structural viroporins (76-109 amino acids) present in the coronavirus. Sixteen sequentially different E proteins were observed from a total of 4917 available complete genomes as on 18th June, 2020 in the NCBI database. The missense mutations over the envelope protein across various coronaviruses of the $\beta$-genus were analyzed to know the immediate parental origin of the envelope protein of SARS-CoV2. The evolutionary origin is also endorsed by the phylogenetic analysis of the envelope proteins comparing sequence homology as well as amino acid conservations.
\end{abstract}

Keywords: Envelope protein; SARS-CoV2; COVID-19; Viroporin; Amino acid conservation; Phylogeny.

\section{Introduction}

A novel coronavirus has been causing the ongoing pandemic which is certainly life threatening as our world is experiencing since December 2019 [1. Coronaviruses (CoV), containing positive-sense RNA as genetic material, cause primarily respiratory infections in humans and a broad range of animals. Recently several new human coronaviruses, including severe acute respiratory syndrome coronavirus (SARS-CoV), MERS-CoV and SARS-CoV2, were identified, which attract scientists in comprehensive understanding of viruses and identification of antiviral targets for development of therapeutic treatments. A CoV contains several proteins (structural, non-structural, accessory etc.) among which two major structural proteins of the coronaviruses (CoVs) are spike (S) and membrane (M) glycoproteins [2]. Every Coronavirus of the $\beta$-genus does contain an envelope (E) protein, containing 75 to 84 amino acids, which plays an essential roles in virus assembly, budding, morphogenesis, entry in the host cell and regulation of other cellular functions [3]. This E protein is an integral membrane protein mainly found in the ERGIC(Endoplasmic ReticulumGolgi Intermediate Compartment) of cells transfected with a plasmid encoding E protein or infected with SARS-CoV [4. Envelope protein of SARS-CoV2 is 75 amino acids long and it possesses three important domains viz. (N)terminus containing 7-9 hydrophilic region, transmembrane domain (TMD) contaning 29 amino acid residues with a high leucine/isoleucine/valine content (hydrophobic region) and (C)-terminus with hydrophilic region (Fig.1) [5].

\footnotetext{
${ }^{*}$ Corresponding author

Email addresses: sarimif@gmail.com (Sk. Sarif Hassan), pabitrapalchoudhury@gmail.com (Pabitra Pal Choudhury), broy@isical.ac.in (Bidyut Roy)
} 


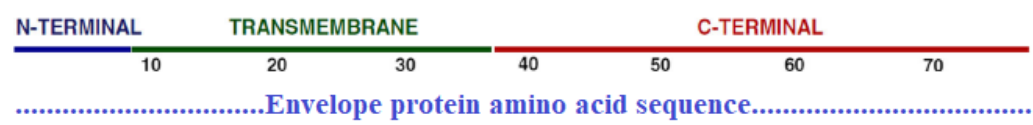

Figure 1: Amino acid sequence and domains of the envelope protein of $\beta$-CoVs

The envelope (E) protein of the coronavirus ( $\mathrm{CoV}$ ) of the $\beta$-genus famiy forms ion channels [6]. The transmembrane domain (TMD) of the E protein is responsible for the observed ion channel activity may attenuate the infectivity. Any missense mutations in the E protein which inhibited ion channel activity engendered attenuation [7, 8]. It is reported that TMD forms stable pentamers and that is confirmed by the molecular simulation and in vitro oligomerization [9]. It is reported that mutation of the hydrophobic amino acid residues in the TMD of the E protein with charged amino acids significantly alter the migrating properties of the E protein [3. Analysis by Y. Liao et al. established that the TMD is essential for the membrane permeabilizing activity of the protein and it also delineates that any missense mutations in the TMD of the E protein disrupt the function of the protein [3]. It is found that the envelope protein of SARS-CoV as well as SARS-CoV2 contains three cysteine residues at positions 40, 43, and 44 respectively [10]. 25 The first and third cysteine residues, at amino acid positions 40 and 44, respectively, were previously reported to play roles in oligomerization of the E protein [11]. Furthermore, from bio-chemical characterization 25 it was learned that it undergoes translational modification by palmitoylation on all three cysteine residues [12. Again, it may be noted from mutagenesis studies that the transmembrane domain is responsible for the membrane permeabilizing activity of the SARS-CoV E protein [13]. The (C)-terminal domain of envelope protein in SARS-CoV2 binds to human PALS1, 30 a tight junction-associated protein, which is essential for the establishment and maintenance of epithelial polarity in mammals [14].

Almost all the proteins embedded in the SARS-CoV2 are being mutating as evidenced over the past few months [15, 16, 17]. It is hard to infer whether the mutations in E protein infect and sicken people deferentially due to COVID-19. In order to comprehend the effect of mutation over various proteins, one needs to accumulate all the mutations over the proteins from wide variety of SARS-CoV2 genomes available worldwide. On the other hand, most unsettled, controversial issue is the source/proximal origin of the SARS-CoV2. 35 Pattern of the genetic differences and motifs of the proteins present in SARS-CoV2 distinguish SARS-CoV2 from any other known coronavirus and this is what makes the discovery of origin hard [18, 19]. Zhang, Wu et al. show that the natural reservoir of SARS-CoV2 are Bat and Pangolin [20]. Recently, based on genomic and protein sequences from few coronoviruses of different hosts including human, reported that Pangolin may not be intermediate host for coronavirus for transmission from bat to human [21]. 40 Presently, we wish to transact the transmission issue by analyzing mutations in one of most conserved proteins (envelope protein) over the SARS-CoV2 and other host-CoV genomes.

In this study, using protein sequences from a large number of coronaviruses from different hosts including human, we analyzed phylogenetic relationship among different hosts. A comparative investigation of the envelope (E) protein 45 of CoVs of the $\beta$-genus family including SARS-CoV2 from the perspective of missense mutations as well as molecular organization of the amino acids in the envelope proteins has been performed in order to gain an insight and discover the intermediate hosts. 


\section{Materials and Methods}

This study considered all the envelope proteins of coronaviruses from different hosts viz. Bat, Camel, Cat, Cattle,

Pangolin, Chimpanzee and human SARS-CoV2. In the Table 1, total number of available CoV genomes of respective hosts as well as distinct number of envelope proteins are presented.

Table 1: Envelope protein of different host-CoVs

\begin{tabular}{cccc}
\hline Host & Total & Distinct & \% of Variability of the E protein \\
\hline Bat & 79 & 25 & $31.646 \%$ \\
Camel & 269 & 9 & $3.346 \%$ \\
Cat & 42 & 17 & $40.476 \%$ \\
Cattle & 22 & 2 & $9.090 \%$ \\
Pangolin & 1 & 1 & $0 \%$ \\
Chimpanzee & 1 & 1 & $0 \%$ \\
SARS-CoV2 & 4917 & 16 & $0.325 \%$ \\
\hline
\end{tabular}

From the NCBI virus database, all the protein sequences of 4917 complete SARS-CoV2 genomes as on date 18th June, 2020 as well as other host CoV genomes were fetched. Then the amino acid sequences of envelope protein of all the CoVs from different hosts viz. Bat, Cat, Cattle, Pangolin, Chimpanzee, Human, are exported in fasta format using file management operations through MATLAB ver. R2020a 22]. The following is the complete list of seventy-two distinct envelope (E) proteins from different host CoVs and their respective protein IDs.

Table 2: List of distinct envelope (E) proteins from different host CoVs and their respective protein ID

\begin{tabular}{|c|c|c|c|c|c|}
\hline Protein ID & Host & Protein ID & Host & Protein ID & Host \\
\hline AIA 62357 & Bat-CoV & AIA62302 & Bat-CoV & ADO39821 & Feline- $\mathrm{CoV}$ \\
\hline AIA62348 & Bat-CoV & AVP78044 & Bat-CoV & ACT10858 & Feline-CoV \\
\hline AHY61342 & Bat-CoV & AVI15004 & Bovine- $\mathrm{CoV}$ & ACT10869 & Feline-CoV \\
\hline ASL68958 & Bat-CoV & AVZ61113 & Bovine-CoV & ACT10909 & Feline-CoV \\
\hline ASL68947 & Bat-CoV & ALA50082 & Camel-CoV & ACT10941 & Feline-CoV \\
\hline ATQ39391 & Bat-CoV & QCI31474 & Camel-CoV & ACT10974 & Feline-CoV \\
\hline AUM60029 & Bat-CoV & QBM11741 & Camel-CoV & ACT10920 & Feline-CoV \\
\hline QDF43841 & Bat-CoV & ASU89926 & Camel-CoV & AWW13513 & Chimpanzee-CoV \\
\hline YP_009072442 & Bat-CoV & ASU90554 & Camel-CoV & QIG55947 & Pangolin CoV \\
\hline YP_009273007 & Bat-CoV & ANI69894 & Camel-CoV & QHZ00381 & Human-SARS-CoV2 \\
\hline ABD75324 & Bat-CoV & ALA49346 & Camel-CoV & QKI36855 & Human-SARS-CoV2 \\
\hline AGC74167 & Bat-CoV & ALA49390 & Camel-CoV & QKG87268 & Human-SARS-CoV2 \\
\hline AKZ19089 & Bat-CoV & ASU90334 & Camel-CoV & QKE45838 & Human-SARS-CoV2 \\
\hline ADK66843 & Bat-CoV & QDM36990 & Feline-CoV & QJR88103 & Human-SARS-CoV2 \\
\hline QDF43816 & Bat-CoV & AYF53097 & Feline-CoV & YP_009724392 & Human-SARS-CoV2 \\
\hline ATO98160 & Bat-CoV & AXE71624 & Feline-CoV & QKI36831 & Human-SARS-CoV2 \\
\hline ATO98184 & Bat-CoV & ASU62492 & Feline-CoV & QJS53352 & Human-SARS-CoV2 \\
\hline QDF43821 & Bat-CoV & ASU62503 & Feline-CoV & QJA42107 & Human-SARS-CoV2 \\
\hline АТО98135 & Bat-CoV & AUG98123 & Feline-CoV & QJQ84210 & Human-SARS-CoV2 \\
\hline AHX37560 & Bat-CoV & AMD11134 & Feline-CoV & QJR89447 & Human-SARS-CoV2 \\
\hline AIA62280 & Bat-CoV & AGT52084 & Feline-CoV & QJI54124 & Human-SARS-CoV2 \\
\hline ABD75313 & Bat-CoV & AEK25514 & Feline-CoV & QKU31207 & Human-SARS-CoV2 \\
\hline \multirow[t]{6}{*}{ AIA62312 } & Bat-CoV & AEK25525 & Feline-CoV & QKU37035 & Human-SARS-CoV2 \\
\hline & & & & QKV07065 & Human-SARS-CoV2 \\
\hline & & & & QKU32371 & Human-SARS-CoV2 \\
\hline & & & & QKU28584 & Human-SARS-CoV2 \\
\hline & & & & QKU52835 & Human-SARS-CoV2 \\
\hline & & & & QKV06741 & Human-SARS-CoV2 \\
\hline
\end{tabular}


Among these 72 different envelope proteins the most common envelope proteins of the respective host CoVs are listed below.

Table 3: Most common envelope proteins across different host CoVs

\begin{tabular}{|c|c|c|}
\hline Host-CoVs & E protein sequence ( $\mathrm{N}$ to $\mathrm{C}$ terminal of protein) & Length \\
\hline Human SARS-CoV2 & MYSFVSEETGTLIVNSVLLFLAFVVFLLVTLAILTALRLCAYCCNIVNVSLVKPSFYVYSRVKNLNSSRVPDLLV & 75 \\
\hline Chimpanzee-CoV & MFMADAYLADTVWYVGQIIFIVAICLLVTIVVVAFLATFKLCIQLCGMCNTLVLSPSIYVFNRGRQFYEFYNDIKPPVLDVDDV & 84 \\
\hline Pangolin-CoV & MYSFVSEETGTLIVNSVLLFLAFVVFLLVTLAILTALRLCAYCCNIVNVSLVKPSFYVYSRVKNLNSSRVPDLLV & 75 \\
\hline Feline or Cat-CoV & MMFPRAFTIIDDHGMVVSVFFWLLLIILILFSIALLNVIKLCMVCCNLGKTIIVLPARHAYDAYKNFMHIKAYDPDEAFLV & 82 \\
\hline Camel-CoV & MLPFVQERIGLFIVNFFIFTVVCAITLLVCMAFLTATRLCVQCITGFNTLLVQPALYLYNTGRSVYVKFQDSKPPLPPDEWV & 82 \\
\hline Cattle or Bovine-CoV & MFMADAYFADTVWYVGQIIFIVAICLLVIIVVVAFLATFKLCIQLCGMCNTLVLSPSIYVFNRGRQFYEFY NDVKPPVLDVDDV & 84 \\
\hline Bat-CoV & MYSFVSEETGTLIVNSVLLFLAFVVFLLVTLAILTALRLCAYCCNIVNVSLVKPTVYVYSRVKNLNSSEGVPDLLV & 76 \\
\hline
\end{tabular}

Amino Acid Conservation Shannon Entropy: For each E protein, Shannon entropy of amino acid conservation over the amino acid sequence of E protein is computed using the following formula [23]:

For a given amino acid sequence of E protein of length $l$, the conservation of amino acids is calculated as follows:

$$
S E=-\sum_{i=1}^{20} p_{s_{i}} \log _{20}\left(p_{s_{i}}\right)
$$

where $p_{s_{i}}=\frac{k_{i}}{l} ; k_{i}$ represents the number of occurrences of an amino acid $s_{i}$ in the given sequence.

\section{Results}

\subsection{Mutations in the E protein of CoVs}

Here we present the missense mutations of the E protein of the CoVs of Bat, Camel, Cat (Feline), Cattle (Bovine) and human SARS-CoV2. It is noted that the envelope (E) protein of the CoVs of Pangolin and Chimpanzee are found to be $100 \%$ conserved as presented in Table 1 and consequently no mutation was found over there. In order to detect the missense mutations, we have made the multiple sequence alignment of the E protein sequences using the Clustal-Omega server [24, 25]. In the following Table 4, description of the amino acid residues and their respective color and property are mentioned. 65 This notations are used in Fig.2.

Table 4: Amino acid residues and their respective color and property used in Fig.2

\begin{tabular}{ccc}
\hline Residue & Colour & Property \\
\hline A,V,F,P,M,I,L and W & RED & hydrophobic (incl.aromatic -Y) \\
D and E & BLUE & Acidic \\
Rand K & MAGENTA & Basic - H \\
S,T,Y,H,C,N,G and Q & GREEN & Hydroxyl + sulfhydryl + amine + G \\
\hline
\end{tabular}

It may be noted that an * (asterisk) indicates positions which have a single, fully conserved residue. Colon (:) indicates conservation between groups of strong similarity. Period (.) indicates conservation between groups of weak similarity [25].

\subsubsection{Missense mutations of the E protein of Bat CoV}

Among 79 available complete $\mathrm{CoV}$ genomes of Bat, twenty-five sequences possess various mutations in the three domains of the E protein as presented in the Fig.2. 
MYELVGTDTSVLIANVLVLIVLCVCIVIVGCAVLLILOFIVSTCTCFFTSVCKPTVYIYN MYELVSADTSVVIANVLLLIIICLFVIVGCALLLVLQFVIGTCGCLFNIICKPTILVYN MLPFVQEQIGSFIVNFFIFTVVCAITLLVCMAFLTATRLCVQCITGVNTLLVQPAVYMYN MLPFVQQQIGSFIVNFFIFTVACAIILLVCMAILTATRLCVQCAVGFNTLLVQPAVYMYN MLPFVQEQIGSFIVNFFIFTVACAIILLVCMAFLTATRLCVQCAIGLNALLVQPAIYVYN MLPFVQEQIGSFIVNFFIFTVACAITLLVCMAFLTATRLCMQCAIGVNTLLVQPAIYVYI MLPFVQEQIGSFIVNFFIFTVACAITLLVCMAFLTATRLCMQCAIGVNTLLVQPAIYVYN MLPFVHEQIGTIIVNFFILTVVCAITLVVCLAILTAIRLCVQCASGVNTLLFVPAFYIYN MLPFVQEQIGAFIVNFFILSVVCAVTLVVCLAILTAIRLCVQCVSGCHTLVFLPAVHIYN MYSFVSQETGTVIVNAVFILVGFVALLIVALAILTCLRLCAYCCNILDQGVVRPTRYVYL MYSFVSEETGTLIVNSVLLFLAFVVFLLVTLAILTALRLCAYCCNIVNVSLVKPSFYVYS MYSFVSEETGTLIVNSVLLFLAFVVFLLVTLAILTALRLCAYCCNIVNVSLVKPTFYVYS MYSFVSEETGTLIVNSVLLFVAFVVFLLVTLAILTALRLCAYCCNIVNVSLVKPTVYVYS MYSFVSEETGTLIVNSVLLFVAFVVFLLVTLAILTALRLCAYCCNIVNVSLVKPTVYVYS MYSFVSEETGTLIVNSVLLFVAFVVFLLVTLAILTALRLCAYCCNIVNVSLVKPTVYVYS MYSFVSEETGTLIVNSVLLFLAFVVFLLVTLAILTALRLCAYCCNIVNVSLVKPTVYVYS MYSFVSEETGTLIVNSVLLFLAFVVFLLVTLAILTALRLCAYCCNIVNVSLVKPTVYVYS MYSFVSEETGTLIVNSVLLFLAFVVFLLVTLAILTALRLCAYCCNIVNVSLVKPTVYVYS MYSFVSEETGTLIVNSVLLFLAFVVFLLVTLAILTALRLCAYCCNIVNVSLVKPTVYVYS MYSFVSEETGTLIVNSVLLFLAFVVFLLVTLAILTALRLCAYCCNIVNVSLVKPTIYVYS MYSFVSEETGTLIVNSVLLFLAFVVFLLVALAILTALRLCAYCCNIVNVSLVKPTVYVYS MYSFVSEETGTLIVNSVLLFLAFVVFLLVTLAILTALRLCAYCCNIVNVSLVKPTVYVYS MYSFVSEETGTLIVNSVLLFVAFVVFLLVTLAILTALRLCAYCCNIVNVSLVKPTVYVYS MYSFVSEETGTLIVNSVLLFFAFVVFLLVTLAILTALRLCAYCCNIVNVSLVKPTVYVYS MYSFVSEETGTLIVNSVLLFFAFVVFLLVTLAILTALRLCAYCCNIVNVSLVKPTVYVYS

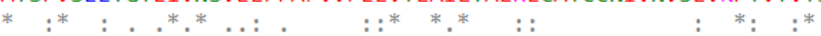

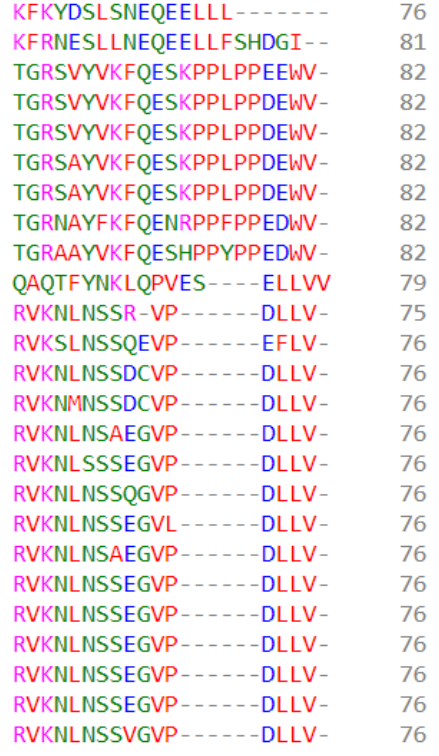

Figure 2: Sequence alignment of the $\mathrm{E}$ protein of $\mathrm{Bat} \mathrm{CoV}$

The missense mutations over the $\mathrm{E}$ proteins of Bat-CoV with the respective domains are described in the Table 5 .

There exists variety of mutations in the envelope proteins of Bat-CoV. 
Table 5: Missense mutations in the envelope protein of the Bat $\mathrm{CoV}$

\begin{tabular}{|c|c|c|}
\hline Protein ID & Mutation & Domain \\
\hline $\begin{array}{l}\text { ATQ39391, AUM60029, AHY61342, ASL68958, } \\
\text { ASL68947, AIA62357, AIA62348 }\end{array}$ & Y2L & $\mathrm{N}$-terminal \\
\hline YP_009072442, AUM60029 & $\mathrm{E} 7 \mathrm{Q}$ & $\mathrm{N}$-terminal \\
\hline QDF 43841 & $\mathrm{E} 7 \mathrm{~A}$ & $\mathrm{~N}$-terminal \\
\hline YP_009273007 & $\mathrm{E} 7 \mathrm{~T}$ & $\mathrm{~N}$-terminal \\
\hline $\begin{array}{l}\text { AIA62348, ASL68947, AIA62357, ASL68958, } \\
\text { AHY61342, AUM60029, ATQ39391 }\end{array}$ & $\mathrm{E} 8 \mathrm{Q}$ & $\mathrm{N}$-terminal \\
\hline QDF 43841, YP_009273007 & $\mathrm{E} 8 \mathrm{D}$ & $\mathrm{N}$-terminal \\
\hline $\begin{array}{l}\text { AIA62348, ASL68947, AIA62357, ASL68958, } \\
\text { AHY61342, AUM60029, ATQ39391 }\end{array}$ & T9I & $\mathrm{N}$-terminal \\
\hline AIA62348 & $\mathrm{T} 11 \mathrm{~A}$ & $\mathrm{~N}$-terminal \\
\hline QDF 43841, YP_009273007 & $\mathrm{T} 11 \mathrm{~V}$ & $\mathrm{~N}$-terminal \\
\hline AIA 62348 & F20S & TMD \\
\hline $\begin{array}{l}\text { ASL68947, AIA62357, ASL68958, AHY61342, } \\
\text { AUM60029, ATQ39391 }\end{array}$ & $\mathrm{F} 20 \mathrm{~T}$ & TMD \\
\hline YP_009072442 & $\mathrm{A} 22 \mathrm{G}$ & TMD \\
\hline $\begin{array}{l}\text { AIA62348, ASL68947, AIA62357, ASL } 68958 \text {, } \\
\text { AHY } 61342 \text {, AUM60029, ATQ39391, QDF } 43841 \text {, YP_009273007 }\end{array}$ & $\mathrm{F} 23 \mathrm{C}$ & TMD \\
\hline YP_009273007 & $\mathrm{V} 25 \mathrm{C}$ & TMD \\
\hline AIA62348, ASL68947, AIA62357, ASL68958, ATQ39391 & $\mathrm{F} 26 \mathrm{~T}$ & TMD \\
\hline AKZ19089, YP_009072442, & T30A & TMD \\
\hline AIA62348, ASL68947, AIA62357, ASL68958, AHY61342, AUM60029, ATQ39391 & T30C & TMD \\
\hline QDF 43841, YP_009273007 & T30G & TMD \\
\hline QDF43841, YP_009273007 & $\mathrm{L} 31 \mathrm{C}$ & TMD \\
\hline QDF43841, YP_009273007 & T35L & TMD \\
\hline YP_009072442 & $\mathrm{A} 36 \mathrm{C}$ & TMD \\
\hline ASL68947, AIA62357, ASL68958, AHY61342, AUM60029, ATQ39391 & L37T & C-terminal \\
\hline QDF43841 & $\mathrm{C} 40 \mathrm{~V}$ & C-terminal \\
\hline YP_009273007 & C40I & C-terminal \\
\hline ASL68947, ASL68958 & $\mathrm{A} 41 \mathrm{M}$ & C-terminal \\
\hline AIA62348 & $\mathrm{C} 44 \mathrm{~V}$ & C-terminal \\
\hline AIA62357, ASL68958, AHY61342, AUM60029 & $\mathrm{C} 44 \mathrm{~A}$ & C-terminal \\
\hline ATQ39391 & $\mathrm{C} 44 \mathrm{I}$ & C-terminal \\
\hline AIA62357, ASL68958, AHY61342 & N45I & C-terminal \\
\hline AUM 60029 & $\mathrm{~N} 45 \mathrm{~V}$ & C-terminal \\
\hline AIA62348, ASL68947, AIA62357, ASL68958, AHY61342, AUM60029, ATQ39391 & $\mathrm{I} 46 \mathrm{G}$ & C-terminal \\
\hline YP_009072442, AUM60029 & $\mathrm{I} 46 \mathrm{C}$ & C-terminal \\
\hline AIA 62348 & $\mathrm{~V} 47 \mathrm{C}$ & C-terminal \\
\hline YP_009072442 & $\mathrm{N} 48 \mathrm{D}$ & C-terminal \\
\hline YP_009072442, AUM60029 & $\mathrm{N} 48 \mathrm{~F}$ & C-terminal \\
\hline YP_009072442 & $\mathrm{V} 49 \mathrm{Q}$ & C-terminal \\
\hline AIA-62348, ASL68947, AIA62357, ASL68958 & $\mathrm{V} 49 \mathrm{~T}$ & C-terminal \\
\hline QDF 43841 & $\mathrm{~V} 49 \mathrm{~N}$ & C-terminal \\
\hline AIA62348, ASL68947, AIA62357, ASL68958, AHY61342, AUM60029, ATQ39391 & S50L & C-terminal \\
\hline QDF 43841 & S50I & C-terminal \\
\hline QDF43841, YP_009273007 & $\mathrm{V} 52 \mathrm{C}$ & C-terminal \\
\hline AIA 62348 & K53L & C-terminal \\
\hline AIA62357 & $\mathrm{K} 53 \mathrm{~V}$ & C-terminal \\
\hline YP_009072442 & V56R & C-terminal \\
\hline QDF43841 & Y $57 \mathrm{~L}$ & C-terminal \\
\hline YP_009072442 & S60L & C-terminal \\
\hline ASL68958 & S60I & C-terminal \\
\hline YP_009072442 & $\mathrm{R} 61 \mathrm{Q}$ & C-terminal \\
\hline AIÁ62348, ASL68947, AIA62357, ASL68958, AHY61342, AUM60029, ATQ39391 & R61T & C-terminal \\
\hline AIA62348, ASL68947, AIA62357, ASL68958, AHY61342, AUM60029, ATQ39391 & V62G & C-terminal \\
\hline YP_009072442 & K63Q & C-terminal \\
\hline YP_009072442 & $\mathrm{N} 64 \mathrm{~A}$ & C-terminal \\
\hline YP_009273007 & L65D & C-terminal \\
\hline QDF43841 & $\mathrm{L} 65 \mathrm{E}$ & C-terminal \\
\hline AIA62348, ASL68947, ASL68958, AHY61342, AUM60029, ATQ39391 & $\mathrm{S} 67 \mathrm{~V}$ & C-terminal \\
\hline AIA62357 & $\mathrm{S} 67 \mathrm{~F}$ & C-terminal \\
\hline QDF43841, YP_009273007 & S67L & C-terminal \\
\hline ATO98160, AIA 62280 & $\mathrm{~S} 68 \mathrm{~A}$ & C-terminal \\
\hline $\begin{array}{l}\text { YP_009072442, AIA62348, ASL68947, AIA62357, ASL68958, } \\
\text { AHY61342, AUM60029, ATQ39391 }\end{array}$ & $\mathrm{S} 68 \mathrm{~K}$ & C-terminal \\
\hline QDF43841, YP_009273007 & $\mathrm{S} 68 \mathrm{~L}$ & C-terminal \\
\hline AGC74167 & $\mathrm{E} 69 \mathrm{~V}$ & C-terminal \\
\hline ATO98135 & $\mathrm{E} 69 \mathrm{Q}$ & C-terminal \\
\hline AVP78044 & $\mathrm{E} 69 \mathrm{R}$ & C-terminal \\
\hline YP_009072442 & $\mathrm{E} 69 \mathrm{~L}$ & C-terminal \\
\hline AIA62348, ASL68947, ASL68958, AHY61342, AUM60029, ATQ39391 & $\mathrm{E} 69 \mathrm{~F}$ & C-terminal \\
\hline QDF43841, YP_009273007 & $\mathrm{E} 69 \mathrm{~N}$ & C-terminal \\
\hline QDF43841, YP_009273007 & $\mathrm{G} 70 \mathrm{E}$ & C-terminal \\
\hline AIA62348, ASL68947, ASL68958, AHY61342, AUM60029, ATQ39391 & $\mathrm{V} 71 \mathrm{E}$ & C-terminal \\
\hline QDF 43841, YP_009273007 & $\mathrm{V} 71 \mathrm{Q}$ & C-terminal \\
\hline AIA62348, ASL68947, ASL68958, AHY61342, AUM60029, ATQ39391 & P72S & C-terminal \\
\hline AIA62357 & $\mathrm{P} 72 \mathrm{~N}$ & C-terminal \\
\hline QDF43841, YP_009273007 & $\mathrm{P} 72 \mathrm{E}$ & C-terminal \\
\hline AIA62348, AIA62357 & $\mathrm{L} 73 \mathrm{D}$ & C-terminal \\
\hline ASL68947, ASL68958, AHY61342, AUM60029, ATQ39391 & L73E & C-terminal \\
\hline QDF 43841 & L73G & C-terminal \\
\hline
\end{tabular}

The most of the frame-shift mutations occurred in the C-terminal domain of the protein. Also there are mutations in other two domains viz. TMD and N-terminal. Clearly, changes in the R-group property from Hydrophobic/Acidic to Hydrophilic/Basic of the amino acid residues of the three domains of the E protein may affect the function of the envelope protein. It is to be noted that envelope protein sequence of the protein QDF43841, YP_009273007, AIA62348 and ATQ39391 possess mutations at the cysteine residue such as C40V, C40I, C44V, C44I respectively. E protein sequence of the proteins AIA62357, ASL68958, AHY61342, AUM60029 contain the mutation C44A. These missense mutation at the cysteine residue would affect virus growth, release, entry, protein transport, and stability [26]. There is 85 an important mutation V25C which is found in the TMD of E protein in the genome YP_009273007, which might stop 
the ion channel activity and led to in vivo attenuation. The TMD of the E protein for Bat CoV genomes AIA62348, ASL68947, AIA62357, ASL68958, ATQ39391 contains a mutation F26T and it may also cause stopping the ion channel activity [27, 28, 29]. Mutations in the motif 'DFLV' might also affect its binding to the PALS1 protein and accordingly may influence replication and/or infectivity of the virus [30].

\subsubsection{Missense mutations of the E protein from Camel CoV}

Among 269 available complete CoV genomes of Camel, only 9 of them possess mutations as presented in the Fig.3.

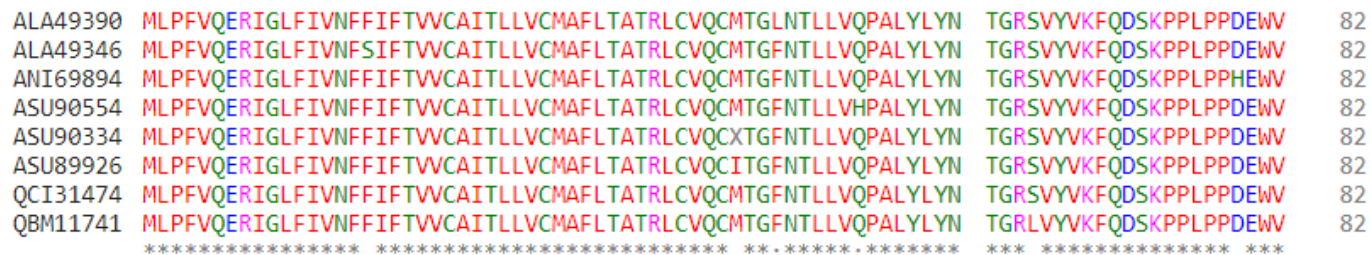

Figure 3: Sequence alignment of the E protein of Camel CoV

Most of the envelope proteins of the Camel $\mathrm{CoV}$ do not contain any mutations, only nine E proteins among the 269 Camel-CoV genomes possess few mutations. The envelope (E) protein possesses only three missense mutations viz. F17S in TMD of the protein ALA49346, S64L and D79H in C-terminal of the proteins QBM11741 and ANI69894 respectively. It is to be noted that the motif is " $D E W V^{\prime \prime}$ in the C-terminal end is absolutely conserved within the host-CoV except in ANI69894.

\subsubsection{Missense mutations of the E protein of Cat CoV}

The highest amount $(40.476 \%)$ of variability among the E proteins is found in the case of Cat-CoV although the mutations over the sequences is limited to seven different positions with $8.536 \%$ over the three domains as presented

in the Fig.4.

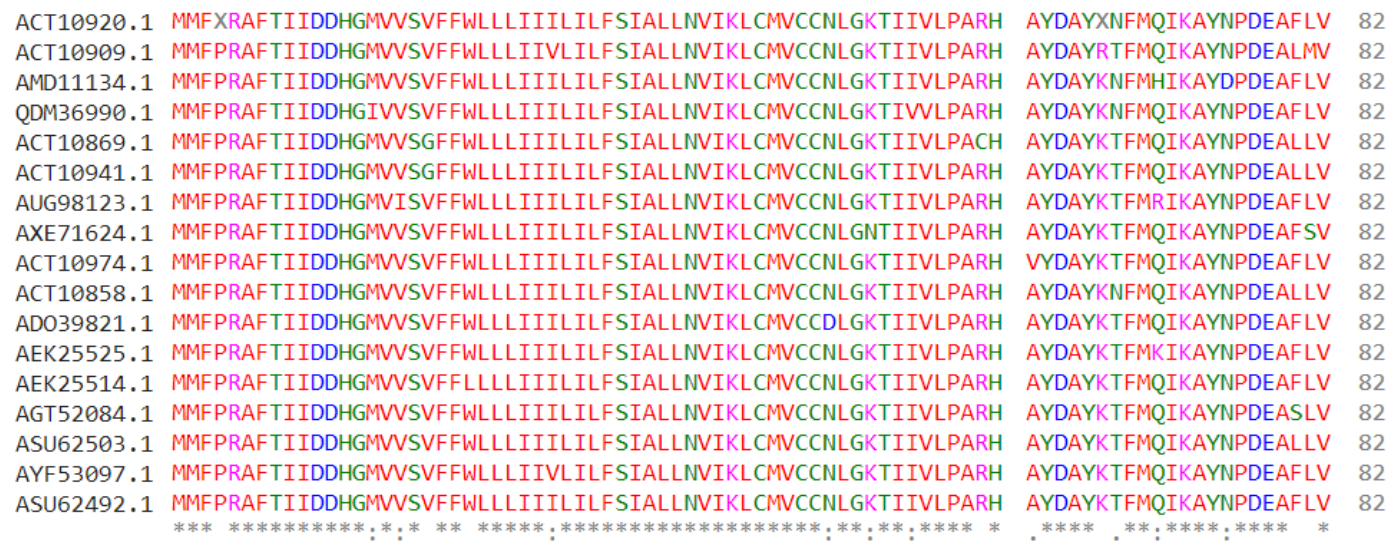

Figure 4: Sequence alignment of the E protein of Cat $\mathrm{CoV}$

These missense mutations over TMD and C-terminal domains of the envelope protein of Cat CoV are shown in Table 6. It is worth noting that though the amount of variability of E proteins is too high comparatively, but the N-terminal of each E protein is absolutely conserved. 
Table 6: Missense mutation of the envelope protein of the Cat $\mathrm{CoV}$

\begin{tabular}{ccc}
\hline Protein ID & Missense Mutations & Domain \\
\hline AXE71624 & K51N, L81S & C-terminal \\
AEK25514 & W22L & TMD \\
ADO39821 & N48D & C-terminal \\
ACT10869 & V19G, R59C & TMD, C-terminal \\
ACT10909 & L81M & C-terminal \\
ACT10941 & V19G & TMD \\
\hline
\end{tabular}

The mutations in the TMD and C-terminal in the $\mathrm{E}$ protein across the Cat $\mathrm{CoV}$ would possibly affect the functions protein in the Cat $\mathrm{CoV}$.

\subsubsection{Missense mutations of the E protein of Cattle CoV}

Among 22 available complete $\mathrm{CoV}$ genomes of Cattle, only two of them had variations due with frame-shifts as shown in Fig.5.

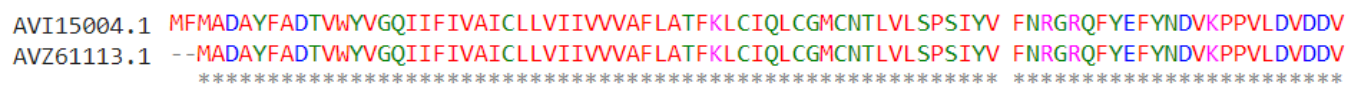

Figure 5: Sequence alignment of the E protein of Cattle CoV .

\begin{abstract}
is to be noted that the mutations in the C-terminal domain of E protein from SARS-CoV to SARS-CoV2 is already
\end{abstract} described in the unpublished article [31].

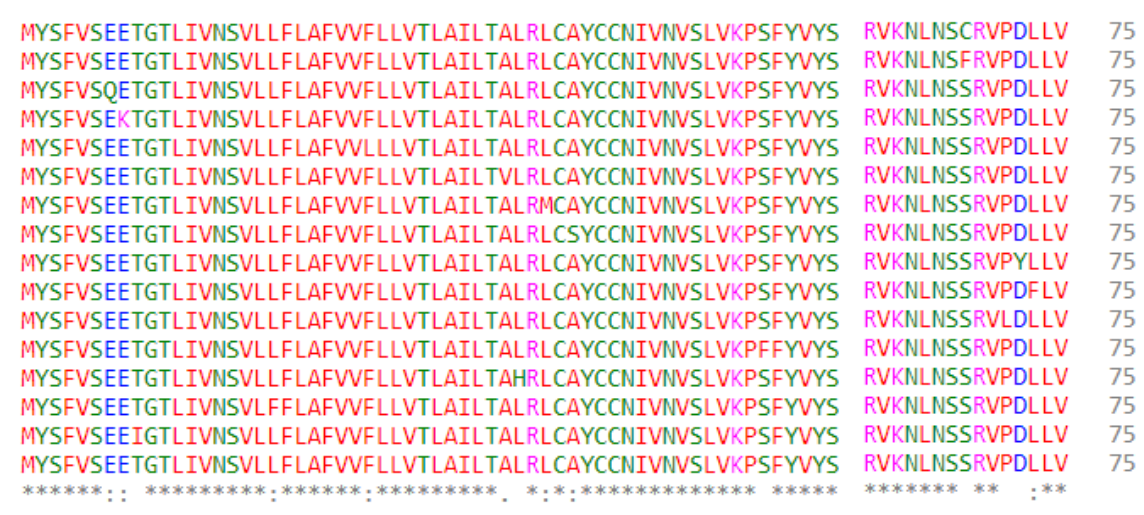

Figure 6: Sequence alignment of the E protein of SARS-CoV2 
Table 7: Protein ID and respective location of mutation of the E proteins over SARS-CoV2

\begin{tabular}{|c|c|c|c|}
\hline Protein ID and Respective Geo-location & Mutations & Domain & R-Group \\
\hline QKO24093 (USA: San Diego, California ) & $\mathrm{E} 8 \mathrm{~K}$ & N-terminal & Acidic to Basic \\
\hline QKU52835 (USA: WA) & E7Q & N-terminal & Acidic to Basic \\
\hline QKN20885 (USA), QJQ84210 (USA: New Orleans, LA) & F26L & TMD & Hydrophobic to Hydrophobic \\
\hline QKI36831 (China: Guangzhou) & $\mathrm{D} 72 \mathrm{Y}$ & C-terminal & Hydrophilic to Hydrophobic \\
\hline QKI36855 (China: Guangzhou) & $\mathrm{S} 68 \mathrm{C}$ & C-terminal & Hydrophilic to Hydrophobic \\
\hline QKG87268, QKG88576 (USA: Massachusetts) & $\mathrm{S} 68 \mathrm{~F}$ & C-terminal & Hydrophilic to Hydrophobic \\
\hline QKE45838 (USA:CA), QKE45886 (USA:CA) & $\mathrm{P} 71 \mathrm{~L}$ & C-terminal & Hydrophobic to Hydrophobic \\
\hline QKE45898 (USA:CA), QKE45910 (USA:CA) & P71L & C-terminal & Hydrophobic to Hydrophobic \\
\hline QJE38284 (USA:CA), QIU81527 (USA:WA), QKV06741 (USA: WA) & $\mathrm{P} 71 \mathrm{~L}$ & C-terminal & Hydrophobic to Hydrophobic \\
\hline QKU32371 (USA: CA) & $\mathrm{P} 71 \mathrm{~L}$ & C-terminal & Hydrophobic to Hydrophobic \\
\hline QJS53352 (Greece: Athens) & L39M & TMD & Hydrophobic to Hydrophobic \\
\hline QJR88103 (Australia: Victoria) & $\mathrm{L} 73 \mathrm{~F}$ & C-terminal & Hydrophobic to Hydrophobic \\
\hline QJA42107 (USA: VA) & A $36 \mathrm{~V}$ & TMD & Hydrophobic to Hydrophobic \\
\hline QHZ00381 (South Korea) & L37H & TMD & Hydrophobic to Hydrophilic \\
\hline QKU31207 (USA: CA) & T9I & TMD & Hydrophilic to Hydrophobic \\
\hline QKU37035 (Saudi Arabia: Jeddah) & L19F & TMD & Hydrophobic to Hydrophobic \\
\hline QKV07065 (USA: WA) & $\mathrm{S} 55 \mathrm{~F}$ & C-terminal & Hydrophilic to Hydrophobic \\
\hline QKU28584 (USA: WA) & $\mathrm{A} 41 \mathrm{~S}$ & C-terminal & Hydrophobic Hydrophilic \\
\hline
\end{tabular}

Only sixteen among 4917 E protein of SARS-CoV2 genomes are distinct and they possess several mutations in all the domains. Most of the missense mutation occurred in the C-terminal. The E protein of QKN20885 (USA) and

QJQ84210 (USA: New Orleans, LA) have a mutation at F26L in the TMD of the E protein. This particular mutation in the TMD terminate the ion channel activity and may led to in vivo attenuation. The E protein of QJS53352 (Greece: Athens), QJA42107 (USA: VA) and QHZ00381 (South Korea) contain mutations L39M, A36V and L37H respectively in the TMD of the E protein. This particular mutation in the TMD terminates the ion channel activity and led to in vivo attenuation. Several mutations have been found in the C-terminal of E proteins of SARS-CoV2 and some of these mutations lead to non-synonymous R-group properties of amino acids, which might affect interaction of E protein with host proteins.

From the mutation data of different host-CoVs, it is concluded that the mutations over the E proteins of the SARS-CoV2, Pangolin CoVs and Bat CoVs are almost similar in nature. It is to be mentioned that the SARS-CoV2 E protein is much close to that of the Pangolin-CoV, from the variability perspective. This closeness is also supported by sequence based homology. Here we illustrate the phylogenetic relationship among the E proteins (most common E protein as mentioned in the Table 3) across different CoVs based on sequence homology, as shown in Fig.7.

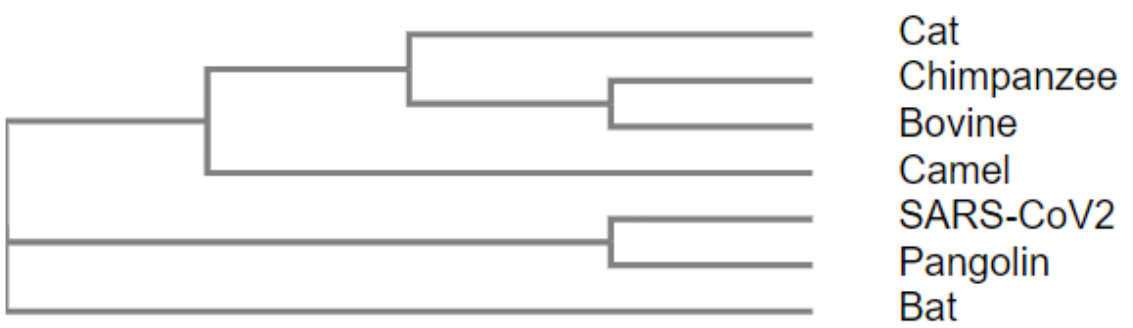

Figure 7: Sequence homology based phylogeny of the envelope protein of different host-CoVs

From the phylogeny Fig.7, it is derived that among all E proteins of all the host CoVs, the E proteins of Pangolin$\mathrm{CoV}$ and SARS-CoV2 are very much close to each other. In order to get more intensive phylogenetic relationship among the E proteins of the host CoVs, we further did amino acid frequency based phylogeny. We determined the 
135 frequency vector for each E protein, pairwise euclidean distance has been calculated and consequently the phylogeny is derived (Fig.8).

Table 8: Amino acid counts over the envelope proteins over the different host CoVs

\begin{tabular}{ccccccccccccccccccccc}
\hline Host-CoVs & A & $\mathbf{R}$ & $\mathbf{N}$ & $\mathbf{D}$ & $\mathbf{C}$ & $\mathbf{Q}$ & $\mathbf{E}$ & $\mathbf{G}$ & $\mathbf{H}$ & $\mathbf{I}$ & $\mathbf{L}$ & $\mathbf{K}$ & $\mathbf{M}$ & $\mathbf{F}$ & $\mathbf{P}$ & $\mathbf{S}$ & $\mathbf{T}$ & $\mathbf{W}$ & $\mathbf{Y}$ & $\mathbf{V}$ \\
\hline SARS-CoV2 & 4 & 3 & 5 & 1 & 3 & 0 & 2 & 1 & 0 & 3 & 14 & 2 & 1 & 5 & 2 & 8 & 4 & 0 & 4 & 13 \\
Chimpanzee-CoV & 6 & 2 & 3 & 6 & 4 & 3 & 1 & 3 & 0 & 8 & 9 & 2 & 3 & 7 & 3 & 2 & 4 & 1 & 5 & 12 \\
Pangolin-CoV & 4 & 3 & 5 & 1 & 3 & 0 & 2 & 1 & 0 & 3 & 14 & 2 & 1 & 5 & 2 & 8 & 4 & 0 & 4 & 13 \\
Cat-CoV & 7 & 2 & 3 & 5 & 3 & 0 & 1 & 2 & 3 & 11 & 11 & 4 & 5 & 7 & 3 & 2 & 2 & 1 & 3 & 7 \\
Camel-CoV & 4 & 3 & 3 & 2 & 4 & 4 & 2 & 3 & 0 & 5 & 11 & 2 & 2 & 8 & 6 & 2 & 7 & 1 & 3 & 10 \\
Bovine-CoV & 6 & 2 & 3 & 6 & 4 & 3 & 1 & 3 & 0 & 8 & 8 & 2 & 3 & 8 & 3 & 2 & 3 & 1 & 5 & 13 \\
Bat-CoV & 4 & 2 & 5 & 1 & 3 & 0 & 3 & 2 & 0 & 3 & 14 & 2 & 1 & 4 & 2 & 7 & 5 & 0 & 4 & 14 \\
\hline
\end{tabular}

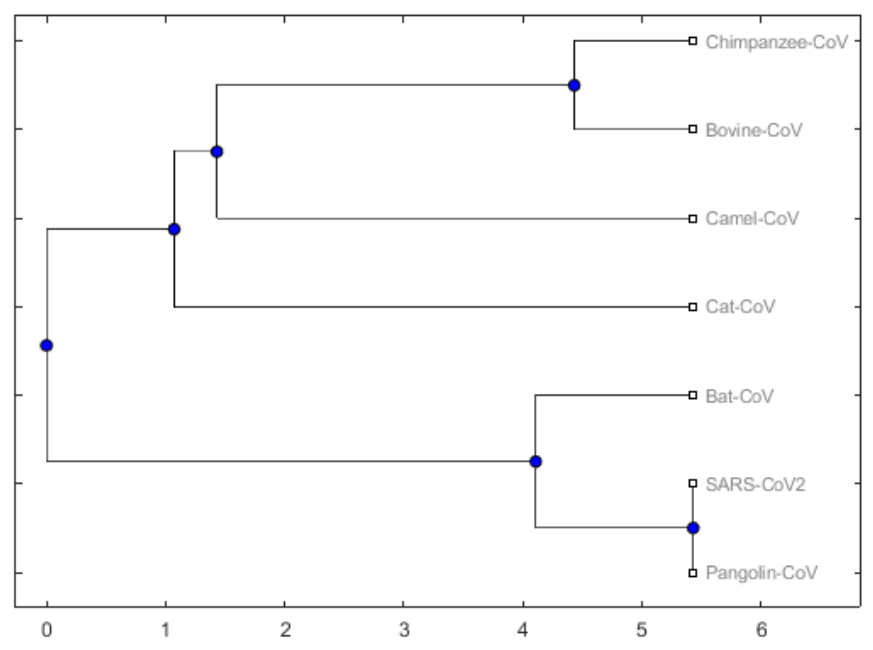

Figure 8: Phylogenetic relationship among the different host CoVs with respect to the amino acids conservation the envelope protein

From the amino acid frequency based phylogeny, it is reconfirmed that the E protein of Bat CoV and SARS-CoV2 are co-evolved from the same origin. Further it is also confirmed that the E protein of Pangolin-CoV and SARS$\mathrm{CoV} 2$ are very much conserved from point of amino acid conservation in the protein. It is worth mentioning that the Chimpanzee-CoV and Bovine-CoVs contain the most closest E proteins as confirmed from the sequence based homology as well as amino acid conservation.

\subsection{Phylogeny of the envelope proteins of host-CoVs}

The sequence based homology of 72 distinct E proteins across the different host CoVs are presented in Fig.9. 


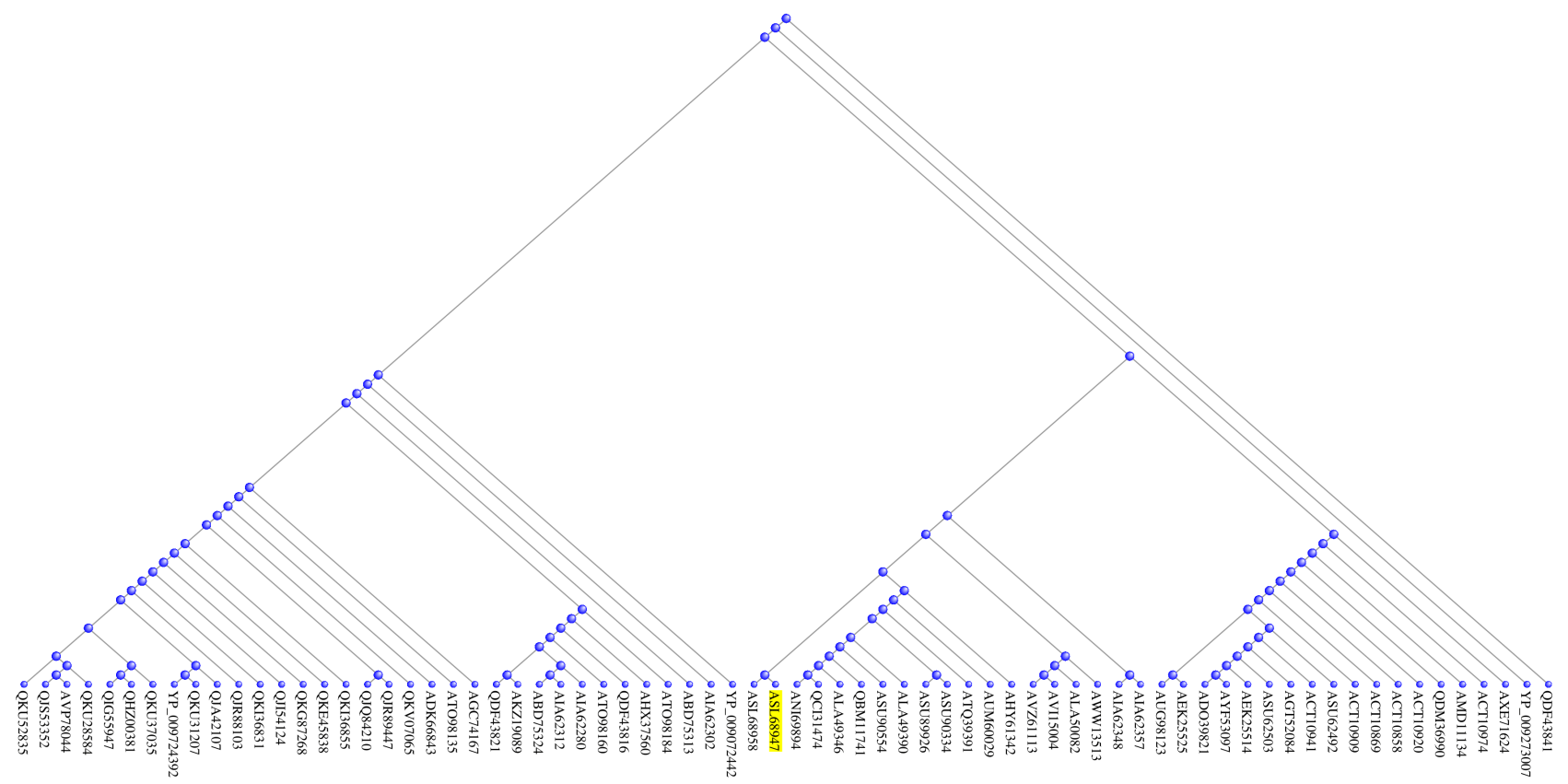

Figure 9: Phylogenetic relationship among envelope proteins of the different host CoVs with respect to the sequence based homology root) exclusively as shown in Fig.9. The other side contains the E proteins of the other host CoVs. It is also observed that all the sixteen different E proteins of SARS-CoV2 and that of Pangolin belong to a near neighbourhood.

In the Table 9, for each of the $\mathrm{E}$ protein of the $\mathrm{CoVs}$, frequency of each amino acids are computed, which yields the amino acids conservation based phylogeny (Fig.10). 
Table 9: Frequency of amino acids over the envelope proteins across the seven different host-CoVs

\begin{tabular}{|c|c|c|c|c|c|c|c|c|c|c|c|c|c|c|c|c|c|c|c|c|c|}
\hline Name & Host & A & $\mathbf{R}$ & $\mathbf{N}$ & D & C & Q & E & G & H & I & L & $\mathrm{K}$ & M & $\mathbf{F}$ & $\mathbf{P}$ & $\mathrm{s}$ & $\mathbf{T}$ & w & $\mathbf{Y}$ & $\mathrm{v}$ \\
\hline ASL68947 & Bat $\mathrm{CoV}$ & 7 & 2 & 3 & 1 & 4 & 5 & 3 & 3 & 0 & 6 & 8 & 2 & 3 & 7 & 6 & 3 & 6 & 1 & 3 & $\overline{9}$ \\
\hline ASU90554 & Camel CoV & 4 & 3 & 3 & 2 & 4 & 3 & 2 & 3 & 1 & 4 & 11 & 2 & 3 & 8 & 6 & 2 & 7 & 1 & 3 & 10 \\
\hline ASL68958 & Bat $\mathrm{CoV}$ & 7 & 2 & 2 & 1 & 4 & 5 & 3 & 3 & 0 & 7 & 8 & 2 & 3 & 7 & 6 & 3 & 6 & 1 & 3 & 9 \\
\hline ANI69894 & Camel CoV & 4 & 3 & 3 & 1 & 4 & 4 & 2 & 3 & 1 & 4 & 11 & 2 & 3 & 8 & 6 & 2 & 7 & 1 & 3 & 10 \\
\hline AXE71624 & Feline CoV & 7 & 2 & 4 & 4 & 3 & 1 & 1 & 2 & 2 & 11 & 10 & 3 & 5 & 7 & 3 & 3 & 3 & 1 & 3 & 7 \\
\hline ALA49346 & Camel CoV & 4 & 3 & 3 & 2 & 4 & 4 & 2 & 3 & 0 & 4 & 11 & 2 & 3 & 7 & 6 & 3 & 7 & 1 & 3 & 10 \\
\hline $\begin{array}{l}\text { AGT52084 } \\
\text { AUM60029 }\end{array}$ & $\begin{array}{l}\text { Feline CoV } \\
\text { Bat } \mathrm{CoV} V\end{array}$ & ${ }_{6}^{7}$ & $\frac{2}{2}$ & $\begin{array}{l}3 \\
3 \\
3\end{array}$ & 4 & $\begin{array}{l}3 \\
4 \\
-1\end{array}$ & ${ }_{6}^{1}$ & $\frac{1}{2}$ & $\begin{array}{l}2 \\
3\end{array}$ & $\begin{array}{l}2 \\
0\end{array}$ & ${ }_{6}^{11}$ & $\begin{array}{c}11 \\
8\end{array}$ & ${ }_{2}^{4}$ & $\begin{array}{l}5 \\
3 \\
3\end{array}$ & $\begin{array}{l}6 \\
7\end{array}$ & $\begin{array}{l}3 \\
6\end{array}$ & $\begin{array}{l}3 \\
3\end{array}$ & $\begin{array}{l}3 \\
5\end{array}$ & 1 & $\begin{array}{l}3 \\
3 \\
3\end{array}$ & ${ }_{11}^{7}$ \\
\hline ACT 10909 & Feline CoV & $\begin{array}{l}6 \\
7\end{array}$ & 3 & $\begin{array}{l}3 \\
3\end{array}$ & 4 & $\begin{array}{l}4 \\
3\end{array}$ & $\begin{array}{l}6 \\
1\end{array}$ & 1 & $\begin{array}{l}3 \\
2\end{array}$ & 2 & $\begin{array}{c}6 \\
10\end{array}$ & 11 & 3 & $\begin{array}{l}3 \\
6\end{array}$ & 6 & $\begin{array}{l}6 \\
3\end{array}$ & $\begin{array}{l}3 \\
2\end{array}$ & $\begin{array}{l}5 \\
3\end{array}$ & 1 & $\begin{array}{l}3 \\
3\end{array}$ & 8 \\
\hline AHY 61342 & Bat $\mathrm{CoV}$ & 7 & 2 & 3 & 1 & 4 & 5 & 3 & 3 & 0 & 7 & 9 & 2 & 2 & 7 & 6 & 3 & 4 & 1 & 3 & 10 \\
\hline AIA 62348 & Bat CoV & 7 & 2 & 2 & 1 & 5 & 4 & 3 & 3 & 3 & 6 & 8 & 1 & 1 & 6 & 6 & 3 & 4 & 1 & 3 & 13 \\
\hline ACT 10941 & Feline CoV & 7 & 2 & 3 & 4 & 3 & 1 & 1 & 3 & 2 & 11 & 12 & 4 & 5 & 6 & 3 & 2 & 3 & 1 & 3 & 6 \\
\hline AYF 53097 & Feline CoV & 7 & 2 & 3 & 4 & 3 & 1 & 1 & 2 & 2 & 10 & 11 & 4 & 5 & 7 & 3 & 2 & 3 & 1 & 3 & 8 \\
\hline $\mathrm{QCI} 31474$ & Camel CoV & 4 & 3 & 3 & 2 & 4 & 4 & 2 & 3 & 0 & 4 & 11 & 2 & 3 & 8 & 6 & 2 & 7 & 1 & 3 & 10 \\
\hline $\begin{array}{l}\text { ASU62492 } \\
\text { ACT10974 }\end{array}$ & $\begin{array}{l}\text { Feline CoV } \\
\text { Feline CoV }\end{array}$ & 7 & 2 & $\begin{array}{l}3 \\
3\end{array}$ & 4 & $\begin{array}{l}3 \\
3 \\
\end{array}$ & 1 & 1 & 2 & 2 & 11 & 11 & 4 & 5 & 7 & 3 & 2 & 3 & 1 & 3 & 7 \\
\hline $\begin{array}{l}\text { ACT10974 } \\
\text { ALA49390 }\end{array}$ & $\begin{array}{l}\text { Feline CoV } \\
\text { Camel CoV }\end{array}$ & $\begin{array}{l}6 \\
4\end{array}$ & $\begin{array}{l}2 \\
3\end{array}$ & $\begin{array}{l}3 \\
3\end{array}$ & ${ }_{2}^{4}$ & $\begin{array}{l}3 \\
4\end{array}$ & $\begin{array}{l}1 \\
4\end{array}$ & $\begin{array}{l}1 \\
2\end{array}$ & $\begin{array}{l}2 \\
3\end{array}$ & $\begin{array}{l}2 \\
0\end{array}$ & $\begin{array}{c}11 \\
4\end{array}$ & $\begin{array}{l}11 \\
12\end{array}$ & $\begin{array}{l}4 \\
2 \\
\end{array}$ & $\begin{array}{l}5 \\
3\end{array}$ & $\begin{array}{l}7 \\
7\end{array}$ & $\begin{array}{l}3 \\
6\end{array}$ & $\begin{array}{l}2 \\
2\end{array}$ & 3 & 1 & $\begin{array}{l}3 \\
3\end{array}$ & 8 \\
\hline $\begin{array}{l}\text { ALA49390 } \\
\text { ASU89926 }\end{array}$ & Camel CoV & 4 & 3 & 3 & 2 & 4 & $\begin{array}{l}4 \\
4\end{array}$ & 2 & $\begin{array}{l}3 \\
3\end{array}$ & 0 & $\begin{array}{l}4 \\
5\end{array}$ & 11 & 2 & $\begin{array}{l}3 \\
2\end{array}$ & 8 & $\begin{array}{l}0 \\
6\end{array}$ & 2 & 7 & $\begin{array}{l}1 \\
1\end{array}$ & 3 & $\begin{array}{l}10 \\
10\end{array}$ \\
\hline ACT 10869 & Feline CoV & 7 & 1 & 3 & 4 & 4 & 1 & 1 & 3 & 2 & 11 & 12 & 4 & 5 & 6 & 3 & 2 & 3 & 1 & 3 & 6 \\
\hline & Bat $\mathrm{CoV}$ & 6 & 3 & 5 & 1 & 4 & 3 & 3 & 3 & 1 & 8 & 8 & 1 & 1 & 8 & 6 & 1 & 6 & 1 & & 10 \\
\hline ASU90334 & Camel CoV & 4 & 3 & 3 & 2 & 4 & 4 & 2 & 3 & 0 & 4 & 11 & 2 & 2 & 8 & 6 & 2 & 7 & 1 & 3 & 10 \\
\hline ASU62503 & Feline CoV & 7 & 2 & 3 & 4 & 3 & 1 & 1 & 2 & 2 & 11 & 12 & 4 & 5 & 6 & 3 & 2 & 3 & 1 & 3 & 7 \\
\hline $\begin{array}{l}\text { ADO39821 } \\
\text { QDM36990 }\end{array}$ & $\begin{array}{l}\text { Feline CoV } \\
\text { Feline CoV }\end{array}$ & $\begin{array}{l}7 \\
7\end{array}$ & $\begin{array}{l}2 \\
2\end{array}$ & ${ }_{4}^{2}$ & $\begin{array}{l}5 \\
4\end{array}$ & $\begin{array}{l}3 \\
3\end{array}$ & ${ }_{1}^{1}$ & $\begin{array}{l}1 \\
1\end{array}$ & $\begin{array}{l}2 \\
2\end{array}$ & ${ }_{2}^{2}$ & $\begin{array}{l}11 \\
11\end{array}$ & $\begin{array}{l}11 \\
11\end{array}$ & ${ }_{4}^{4}$ & $\begin{array}{l}5 \\
4\end{array}$ & $\begin{array}{l}7 \\
7\end{array}$ & $\begin{array}{l}3 \\
3\end{array}$ & $\begin{array}{l}2 \\
2\end{array}$ & $\begin{array}{l}3 \\
2\end{array}$ & $\begin{array}{l}1 \\
1\end{array}$ & $\begin{array}{l}3 \\
3 \\
3\end{array}$ & $\begin{array}{l}7 \\
8\end{array}$ \\
\hline ACT10858 & Feline CoV & 7 & 2 & $\begin{array}{l}4 \\
4\end{array}$ & $\begin{array}{l}4 \\
4\end{array}$ & $\begin{array}{l}3 \\
3\end{array}$ & 1 & 1 & $\begin{array}{l}2 \\
2\end{array}$ & $\begin{array}{l}2 \\
2\end{array}$ & 11 & 11 & $\begin{array}{l}4 \\
4\end{array}$ & $\begin{array}{l}4 \\
5\end{array}$ & 6 & $\begin{array}{l}3 \\
3\end{array}$ & $\begin{array}{l}2 \\
2\end{array}$ & 2 & $\begin{array}{l}1 \\
1\end{array}$ & $\begin{array}{l}3 \\
3\end{array}$ & \\
\hline AWW 13513 & Chimpanzee CoV & 6 & 2 & 3 & 6 & 4 & 3 & 1 & 3 & 0 & 8 & 9 & 2 & 3 & 7 & 3 & 2 & 4 & 1 & 5 & 12 \\
\hline АCT 10920 & Feline CoV & 7 & 2 & 4 & 4 & 3 & 1 & 1 & 2 & 2 & 11 & 11 & 3 & 5 & 7 & 2 & 2 & 2 & 1 & 3 & 7 \\
\hline ATQ39391 & Bat CoV & 4 & 2 & 3 & 0 & 4 & 5 & 4 & 3 & 0 & 5 & 8 & 2 & 3 & 7 & 6 & 3 & 7 & 1 & & 12 \\
\hline $\begin{array}{l}\text { QBM11741 } \\
\text { AVI15004 }\end{array}$ & $\begin{array}{l}\text { Camel CoV } \\
\text { Bovine CoV }\end{array}$ & ${ }_{6}^{4}$ & $\begin{array}{l}3 \\
2\end{array}$ & $\begin{array}{l}3 \\
3\end{array}$ & $\begin{array}{l}2 \\
6\end{array}$ & $\begin{array}{l}4 \\
4\end{array}$ & $\begin{array}{l}4 \\
3\end{array}$ & $\begin{array}{l}2 \\
1\end{array}$ & $\begin{array}{l}3 \\
3 \\
3\end{array}$ & $\begin{array}{l}0 \\
0\end{array}$ & ${ }_{8}^{4}$ & $\begin{array}{c}12 \\
8\end{array}$ & $\begin{array}{l}2 \\
2\end{array}$ & $\begin{array}{l}3 \\
3 \\
3\end{array}$ & $\begin{array}{l}8 \\
8\end{array}$ & $\begin{array}{l}6 \\
3\end{array}$ & $\frac{1}{2}$ & $\begin{array}{l}7 \\
3\end{array}$ & 1 & $\begin{array}{l}3 \\
5\end{array}$ & $\begin{array}{l}10 \\
13 \\
13\end{array}$ \\
\hline AUG98123 & Feline CoV & 7 & 3 & 3 & 4 & 3 & 0 & 1 & 2 & 2 & 12 & 11 & 4 & 5 & $\frac{8}{7}$ & 3 & 2 & 3 & 1 & 3 & 6 \\
\hline AMD 1 & Feline CoV & 7 & 2 & 3 & 5 & 3 & 0 & 1 & 2 & 3 & 11 & 11 & 4 & 5 & 7 & 3 & 2 & 2 & 1 & 3 & 7 \\
\hline AEK25525 & Feline CoV & 7 & 2 & 3 & 4 & 3 & 0 & 1 & 2 & 2 & 11 & 11 & 5 & 5 & 7 & 3 & 2 & 3 & 1 & 3 & 7 \\
\hline AVZ61113 & Bovine CoV & 6 & 2 & 3 & 6 & 4 & 3 & 1 & 3 & 0 & 8 & 8 & 2 & 2 & 7 & 3 & 2 & 3 & 1 & 5 & 13 \\
\hline $\begin{array}{l}\text { ALA50082 } \\
\text { AEK 25514 }\end{array}$ & $\begin{array}{l}\text { Camel CoV } \\
\text { Feline CoV }\end{array}$ & 6 & 2 & 3 & 6 & 4 & 3 & 1 & 3 & 0 & 9 & 8 & 2 & 2 & 8 & 3 & 2 & 3 & 1 & 5 & 13 \\
\hline $\begin{array}{l}\text { AEK255514 } \\
\text { YP_009072442 }\end{array}$ & Feline CoV & ${ }_{6}^{7}$ & 2 & $\begin{array}{l}3 \\
3\end{array}$ & ${ }_{1}^{4}$ & $\begin{array}{l}3 \\
4\end{array}$ & $\frac{1}{5}$ & 1 & 2 & 2 & 11 & 12 & 4 & 5 & 7 & 3 & 2 & $\begin{array}{l}3 \\
5\end{array}$ & $\begin{array}{l}0 \\
0 \\
0\end{array}$ & $\begin{array}{l}3 \\
5\end{array}$ & 7 \\
\hline QDF 43841 & Bat CoV & $\begin{array}{l}0 \\
3\end{array}$ & 1 & $\begin{array}{l}3 \\
5\end{array}$ & $\begin{array}{l}1 \\
2\end{array}$ & $\begin{array}{l}4 \\
5\end{array}$ & $\begin{array}{l}5 \\
2\end{array}$ & $\begin{array}{l}3 \\
5\end{array}$ & 4 & 1 & $\begin{array}{c}5 \\
10\end{array}$ & 15 & $\begin{array}{l}1 \\
2\end{array}$ & 1 & $\begin{array}{l}4 \\
5\end{array}$ & 1 & 4 & $\begin{array}{l}5 \\
3\end{array}$ & 0 & $\begin{array}{l}5 \\
2\end{array}$ & $\begin{array}{l}13 \\
10\end{array}$ \\
\hline YP_009273007 & Bat $\mathrm{CoV}$ & 2 & 0 & 3 & 2 & 6 & 2 & 4 & 2 & 0 & 7 & 12 & 3 & 1 & 4 & 1 & 5 & 6 & 0 & 4 & 12 \\
\hline & SARS-CoV2 & 4 & 3 & 5 & 1 & 3 & 0 & 2 & 1 & 1 & 3 & 13 & 2 & 1 & 5 & 2 & 8 & 4 & 0 & 4 & 13 \\
\hline & & 4 & 2 & 5 & 1 & 3 & 1 & 2 & 2 & 0 & 3 & & 2 & 1 & 4 & 2 & 7 & 5 & 0 & & 14 \\
\hline AIA62302 & Bat CoV & 4 & 2 & 5 & 2 & 4 & 0 & 2 & 1 & 0 & 3 & 12 & 2 & 2 & 4 & 2 & 7 & 5 & 0 & 4 & 15 \\
\hline & $\begin{array}{c}\text { SARS- } \\
\text { Bat }\end{array}$ & $\begin{array}{l}4 \\
4\end{array}$ & $\begin{array}{l}3 \\
2\end{array}$ & $\begin{array}{l}5 \\
5\end{array}$ & $\begin{array}{l}1 \\
1\end{array}$ & $\begin{array}{l}3 \\
3\end{array}$ & $\begin{array}{l}0 \\
0 \\
0\end{array}$ & $\begin{array}{l}2 \\
3\end{array}$ & $\begin{array}{l}1 \\
2\end{array}$ & $\begin{array}{l}0 \\
0\end{array}$ & $\begin{array}{l}3 \\
4\end{array}$ & $\begin{array}{l}13 \\
14\end{array}$ & $\begin{array}{l}2 \\
2\end{array}$ & $\begin{array}{l}2 \\
1\end{array}$ & $\begin{array}{l}5 \\
4\end{array}$ & $\begin{array}{l}2 \\
2\end{array}$ & $\begin{array}{l}8 \\
7\end{array}$ & $\begin{array}{l}4 \\
5\end{array}$ & $\begin{array}{l}0 \\
0 \\
0\end{array}$ & & $\begin{array}{l}13 \\
13\end{array}$ \\
\hline $\mathrm{ABD}$ & $\mathrm{Ba}$ & 4 & 2 & 5 & 1 & 3 & 0 & 3 & 2 & 0 & 3 & 13 & 2 & 1 & 5 & 2 & 7 & 5 & c & 4 & 14 \\
\hline & B & 4 & 2 & 4 & 0 & 3 & 1 & 4 & 1 & 0 & 3 & & 2 & 1 & 6 & 2 & 8 & 5 & 0 & 4 & 13 \\
\hline & & 5 & 2 & 5 & 1 & 3 & 0 & 3 & 2 & 0 & 3 & & 2 & 1 & 4 & 2 & 6 & 5 & 0 & 4 & 14 \\
\hline AIA62280 & Bat CoV & 5 & 2 & 5 & 1 & 3 & 0 & 3 & 2 & 0 & 3 & 13 & 2 & 1 & 4 & 2 & 6 & 5 & 0 & 4 & 15 \\
\hline & SARS-CoV2 & 4 & 3 & 5 & 1 & 3 & ${ }_{0}^{0}$ & 2 & 1 & 0 & 3 & 13 & 2 & 1 & ${ }_{4}^{6}$ & 2 & 8 & 4 & 0 & 4 & 13 \\
\hline & $\begin{array}{l}\text { Bat } C \mathrm{Co} \\
\text { Bat } C \mathrm{C}\end{array}$ & $\begin{array}{l}5 \\
4\end{array}$ & $\begin{array}{l}2 \\
2\end{array}$ & $\begin{array}{l}5 \\
5\end{array}$ & $\begin{array}{l}1 \\
1\end{array}$ & $\begin{array}{l}3 \\
3\end{array}$ & $\begin{array}{l}0 \\
0\end{array}$ & $\begin{array}{l}3 \\
3\end{array}$ & $\begin{array}{l}2 \\
2\end{array}$ & $\begin{array}{l}0 \\
0\end{array}$ & $\begin{array}{l}3 \\
3\end{array}$ & $\begin{array}{l}4 \\
4\end{array}$ & $\begin{array}{l}2 \\
2\end{array}$ & $\begin{array}{l}1 \\
1\end{array}$ & $\begin{array}{l}4 \\
4\end{array}$ & $\begin{array}{l}2 \\
2\end{array}$ & $\begin{array}{l}7 \\
7\end{array}$ & $\begin{array}{l}4 \\
5\end{array}$ & $\begin{array}{l}0 \\
0\end{array}$ & $\begin{array}{l}4 \\
4\end{array}$ & $\begin{array}{l}14 \\
14\end{array}$ \\
\hline & & 4 & 3 & 5 & 1 & 4 & 0 & 2 & 1 & 0 & 3 & & 2 & 1 & 5 & 2 & 7 & 4 & 0 & 4 & 13 \\
\hline & & 4 & 2 & 5 & 1 & 3 & 0 & 3 & 2 & 0 & 3 & & 2 & 1 & 4 & 2 & 7 & 5 & & 4 & 15 \\
\hline$A B D$ & & 4 & 2 & 5 & 2 & 4 & 0 & 2 & 1 & 0 & 3 & & 2 & 1 & 4 & 2 & 7 & 5 & 0 & 4 & 15 \\
\hline & SARS- & 4 & 3 & 5 & 1 & 3 & 0 & 2 & 1 & 0 & 3 & & 2 & 1 & 6 & 2 & 7 & 4 & 0 & 4 & 13 \\
\hline${ }_{A G X 3}$ & & 4 & 2 & 4 & 1 & $\begin{array}{l}3 \\
3 \\
3\end{array}$ & $\begin{array}{l}0 \\
0\end{array}$ & $\begin{array}{l}3 \\
2\end{array}$ & 2 & $\begin{array}{l}0 \\
0\end{array}$ & $\begin{array}{l}3 \\
3\end{array}$ & 14 & 2 & 1 & 4 & 2 & 8 & 5 & $\begin{array}{l}0 \\
0 \\
0\end{array}$ & 4 & 14 \\
\hline & & $\begin{array}{l}4 \\
4\end{array}$ & $\begin{array}{l}2 \\
3\end{array}$ & $\begin{array}{l}5 \\
5\end{array}$ & $\begin{array}{l}1 \\
1\end{array}$ & $\begin{array}{l}3 \\
3\end{array}$ & $\begin{array}{l}0 \\
0\end{array}$ & $\begin{array}{l}2 \\
2\end{array}$ & $\begin{array}{l}2 \\
1\end{array}$ & $\begin{array}{l}0 \\
0\end{array}$ & $\begin{array}{l}3 \\
3\end{array}$ & & $\begin{array}{l}2 \\
2\end{array}$ & $\begin{array}{l}1 \\
1\end{array}$ & 5 & $\begin{array}{l}2 \\
2\end{array}$ & $\begin{array}{l}7 \\
8\end{array}$ & $\begin{array}{l}5 \\
4\end{array}$ & & & $\begin{array}{l}15 \\
13\end{array}$ \\
\hline & & 4 & 3 & 5 & 1 & 3 & 0 & 2 & 1 & 0 & 3 & & 2 & 1 & 5 & 2 & 8 & 4 & 0 & 4 & 13 \\
\hline & & 4 & 3 & 5 & 1 & 3 & 0 & 2 & 1 & 0 & 3 & & 2 & 1 & 5 & 2 & 8 & 4 & 0 & 4 & 13 \\
\hline & & 4 & 3 & 5 & 1 & 3 & 0 & 2 & 1 & 0 & 3 & 14 & 2 & 1 & 5 & 2 & 8 & 4 & 0 & 4 & 12 \\
\hline & $\begin{array}{l}R S-C o \\
R S S\end{array}$ & 4 & 3 & 5 & 1 & 3 & ${ }_{0}^{0}$ & 2 & 1 & 0 & 3 & 15 & 2 & 1 & 4 & 2 & 8 & 4 & 0 & 4 & 13 \\
\hline & & 3 & 3 & 5 & 1 & $\begin{array}{l}3 \\
3 \\
3\end{array}$ & $\begin{array}{l}0 \\
0\end{array}$ & 2 & 1 & $\begin{array}{l}0 \\
0\end{array}$ & $\begin{array}{l}3 \\
3\end{array}$ & 14 & 2 & 1 & 5 & 2 & 8 & 4 & & 4 & 14 \\
\hline & & $\begin{array}{l}4 \\
4\end{array}$ & $\begin{array}{l}2 \\
3\end{array}$ & $\begin{array}{l}5 \\
5\end{array}$ & $\begin{array}{l}1 \\
1\end{array}$ & & & $\begin{array}{l}3 \\
2\end{array}$ & 1 & & $\begin{array}{l}3 \\
3 \\
3\end{array}$ & & $\begin{array}{l}2 \\
2\end{array}$ & & 4 & $\begin{array}{l}1 \\
1\end{array}$ & $\begin{array}{l}7 \\
8\end{array}$ & $\begin{array}{l}5 \\
4\end{array}$ & & & $\begin{array}{l}14 \\
13\end{array}$ \\
\hline & & 4 & 3 & 5 & 0 & & & 2 & 1 & & 3 & & & & & 2 & & $\begin{array}{l}4 \\
4 \\
4\end{array}$ & & & \\
\hline & & 4 & 3 & 5 & 0 & 3 & 0 & 2 & 1 & 0 & 3 & & 2 & & 5 & 2 & 8 & 4 & & 4 & 3 \\
\hline & & 4 & 3 & 5 & 1 & 3 & 0 & 2 & 1 & 0 & 4 & & 2 & 1 & 5 & 2 & 8 & 3 & & 4 & \\
\hline & & 4 & 3 & 5 & 1 & 3 & 0 & 2 & 1 & 0 & 3 & $1 x_{2}>$ & 2 & & 6 & 2 & & 4 & & & \\
\hline & & 4 & 3 & 5 & 1 & 3 & 0 & 2 & 1 & 0 & 3 & 14 & 2 & & 6 & 2 & & 4 & & 4 & \\
\hline & & 3 & 3 & 5 & 1 & 3 & 0 & 2 & 1 & 0 & 3 & 14 & 2 & 1 & 5 & 2 & 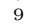 & 4 & & & \\
\hline QKU52835 & SARS-CoV2 & 4 & 3 & 5 & 1 & 3 & 1 & 1 & 1 & 0 & 3 & 14 & 2 & 1 & 5 & 2 & 8 & 4 & 0 & 4 & 13 \\
\hline
\end{tabular}




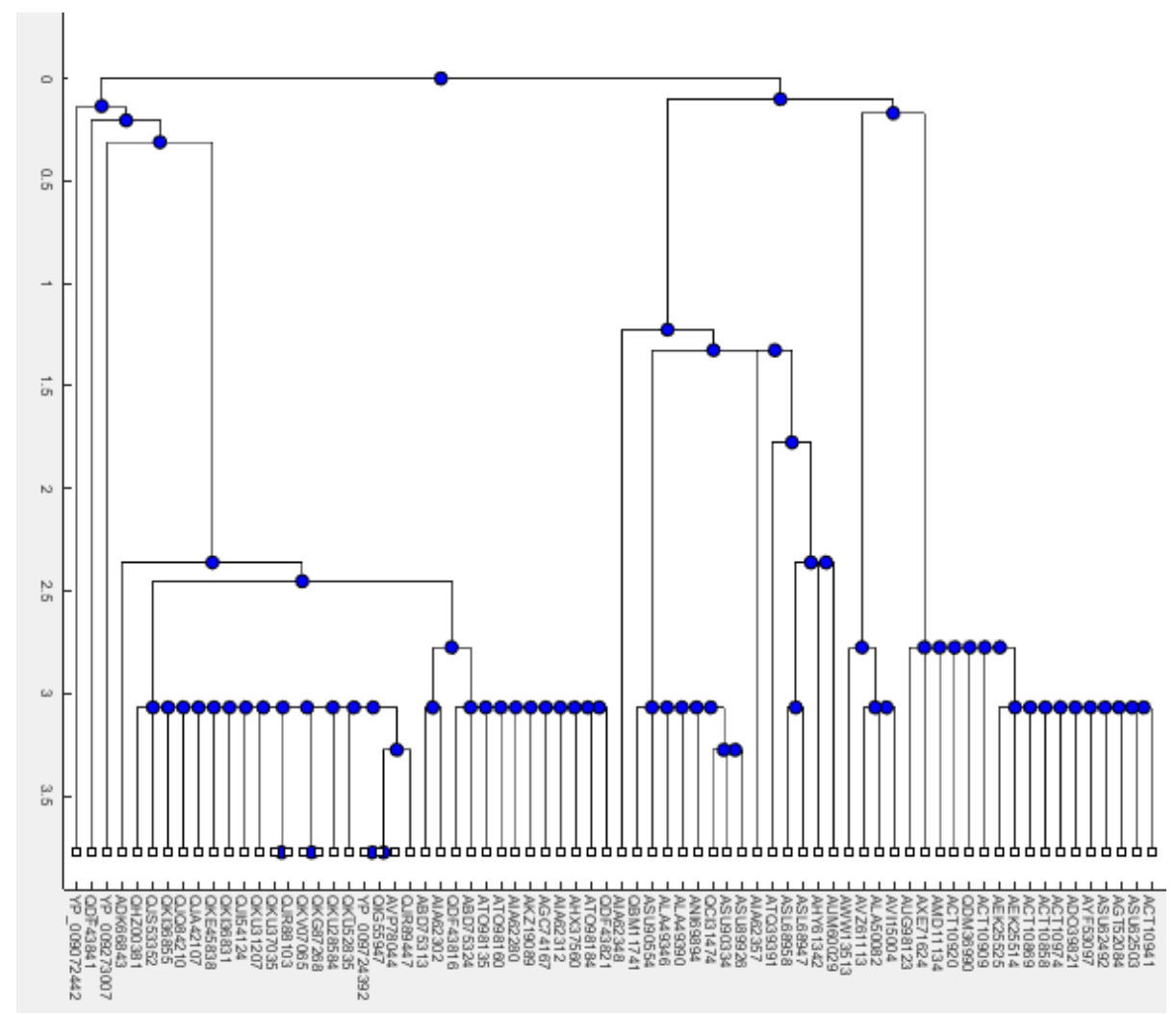

Figure 10: Phylogenetic relationship among envelope proteins of the different host CoVs with respect to the amino acids conservation are very much close. Based on the amino acid conservation over the E protein, the phylogeny (Fig.10) further showed that the E proteins of QDF43821, ATO98184, AHX37560, AGC74167, AKZ19089, AIA62280, ATO98160, ATO98135 of Bat-CoV are in the same branch with same level of the phylogeny. The phylogeny in Fig.9 describe that the E proteins of QJR89447 and QJQ84210 of SARS-CoV2 are very close. It is obtained that the E proteins of AVP78044 from the phylogeny based on amino acid conservations (Fig.10). The E proteins of QKI36855, QJA42107, QKE45838, QKI36831 and QJI54124 of SARS-CoV2 are in the close proximity to that of the QJQ84210 (SARS-CoV2) based on amino acid conservations. Again the E proteins of QKU31207 and YP_009724392 of SARS-CoV2 are found to be near enough based on the homology based phylogeny.

It is observed that almost all the E proteins of SARS-CoV2 as well as Bat and Pangolin-CoVs do not contain the amino acids 155 tryptophan, glutamine and histidine. The E proteins of all the host CoVs are leucine and valine residues rich as observed in Table 10.

Based on the amino acid frequency vector for each proteins, the Shannon entropy (SE) is computed which is tabulated in Table 10. This SE of the amino acid conservation of the E protein suggests molecular level closeness of the E protein. 
Table 10: Shannon entropy of the amino acid conservation of the E protein of the host CoVs

\begin{tabular}{|c|c|c|c|c|c|c|c|c|}
\hline Name & Host & SE & Name & Host & SE & Name & Host & SE \\
\hline ASL68947 & Bat $\mathrm{CoV}$ & 0.933 & ACT10858 & Feline CoV & 0.919 & AIA62280 & Bat CoV & 0.851 \\
\hline ASU90554 & Camel CoV & 0.932 & AWW13513 & Chimpanzee $\mathrm{CoV}$ & 0.918 & QJR88103 & SARS-CoV2 & 0.850 \\
\hline ASL68958 & Bat $\mathrm{CoV}$ & 0.930 & ACT10920 & Feline $\mathrm{CoV}$ & 0.916 & QKU37035 & SARS-CoV2 & 0.850 \\
\hline ANI69894 & Camel CoV & 0.929 & ATQ39391 & Bat CoV & 0.916 & AKZ19089 & Bat CoV & 0.850 \\
\hline AXE71624 & Feline $\mathrm{CoV}$ & 0.928 & QBM11741 & Camel CoV & 0.915 & QDF43821 & Bat $\mathrm{CoV}$ & 0.850 \\
\hline ALA49346 & Camel CoV & 0.927 & AVI15004 & Bovine $\mathrm{CoV}$ & 0.914 & QKI36855 & SARS-CoV2 & 0.850 \\
\hline AGT52084 & Feline CoV & 0.926 & AUG98123 & Feline $\mathrm{CoV}$ & 0.912 & AIA 62312 & Bat CoV & 0.849 \\
\hline AUM60029 & Bat $\mathrm{CoV}$ & 0.926 & AMD11134 & Feline $\mathrm{CoV}$ & 0.912 & ABD75313 & Bat $\mathrm{CoV}$ & 0.848 \\
\hline ACT10909 & Feline $\mathrm{CoV}$ & 0.926 & AEK25525 & Feline $\mathrm{CoV}$ & 0.912 & QKG87268 & SARS-CoV2 & 0.848 \\
\hline AHY61342 & Bat CoV & 0.925 & AVZ61113 & Bovine $\mathrm{CoV}$ & 0.912 & QKV07065 & SARS-CoV2 & 0.848 \\
\hline AIA 62348 & Bat $\mathrm{CoV}$ & 0.925 & ALA50082 & Camel CoV & 0.909 & AHX37560 & Bat CoV & 0.847 \\
\hline ACT10941 & Feline CoV & 0.924 & AEK25514 & Feline CoV & 0.908 & AGC74167 & Bat $\mathrm{CoV}$ & 0.847 \\
\hline AYF53097 & Feline $\mathrm{CoV}$ & 0.924 & YP_009072442 & Bat $\mathrm{CoV}$ & 0.888 & AVP78044 & Bat $\mathrm{CoV}$ & 0.846 \\
\hline QCI31474 & Camel CoV & 0.923 & QDF43841 & Bat $\mathrm{CoV}$ & 0.881 & QIG55947 & Pangolin $\mathrm{CoV}$ & 0.846 \\
\hline ASU62492 & Feline $\mathrm{CoV}$ & 0.922 & YP_009273007 & Bat CoV & 0.868 & YP_009724392 & SARS-CoV2 & 0.846 \\
\hline ACT10974 & Feline $\mathrm{CoV}$ & 0.922 & QHZ00381 & SARS-CoV2 & 0.862 & QKU31207 & SARS-CoV2 & 0.846 \\
\hline ALA49390 & Camel CoV & 0.921 & ATO98135 & Bat CoV & 0.858 & QJR89447 & SARS-CoV2 & 0.843 \\
\hline ASU89926 & Camel CoV & 0.921 & AIA62302 & Bat CoV & 0.857 & QKU28584 & SARS-CoV2 & 0.842 \\
\hline ACT10869 & Feline $\mathrm{CoV}$ & 0.920 & QJS53352 & SARS-CoV2 & 0.856 & QJQ84210 & SARS-CoV2 & 0.841 \\
\hline AIA62357 & Bat $\mathrm{CoV}$ & 0.920 & QDF43816 & Bat CoV & 0.856 & QJA42107 & SARS-CoV2 & 0.840 \\
\hline ASU90334 & Camel CoV & 0.920 & ABD75324 & Bat $\mathrm{CoV}$ & 0.855 & ATO98184 & Bat CoV & 0.840 \\
\hline ASU62503 & Feline $\mathrm{CoV}$ & 0.920 & ADK66843 & Bat CoV & 0.852 & QKE45838 & SARS-CoV2 & 0.836 \\
\hline ADO39821 & Feline CoV & 0.920 & QKU52835 & SARS-CoV2 & 0.852 & QKI36831 & SARS-CoV2 & 0.835 \\
\hline QDM36990 & Feline $\mathrm{CoV}$ & 0.919 & ATO98160 & Bat CoV & 0.851 & QJI54124 & SARS-CoV2 & 0.824 \\
\hline
\end{tabular}

From the Table 10, it is quite evident that the conservation of amino acids over the E protein of Bat-CoV is highly diverse as SE value is in the interval of 0.84 and 0.94 whereas SE of most common E protein of SARS-CoV2 and that of the Pangolin-CoV are found to be identical and it is close to 0.846. Note that, there is an E protein of AVP78044 (Bat $\mathrm{CoV}$ ) whose SE is also identical to 0.846 . The remaining fifteen different $\mathrm{E}$ proteins of SARS-CoV2 are close enough to other Bat-CoVs by accumulating various missense mutations. The SE of the E protein of SARS-CoV2 lies in between 0.824 and 0.862 . There are E proteins of SARS-CoV2 whose SE of amino acid conservation is tightly bounded by that of Pangolin and Bat-CoVs. It is found that SE of E proteins of ADK66843 (Bat CoV) and QKU52835 (SARS-CoV2) are turned out to be identical (0.852). There are other such examples too which are clearly observed in the Table 10. This phylogenetic relationship is endorsed by the amino acid conservation and their associated SE found in Table 10.

We also observed phylogenetic relationship among E proteins from Bat-CoV, Pangolin-CoV and SARS-CoV2 (Fig.11).

This relationship was drawn using amino acid conservation and their associated SE (Table 10). 


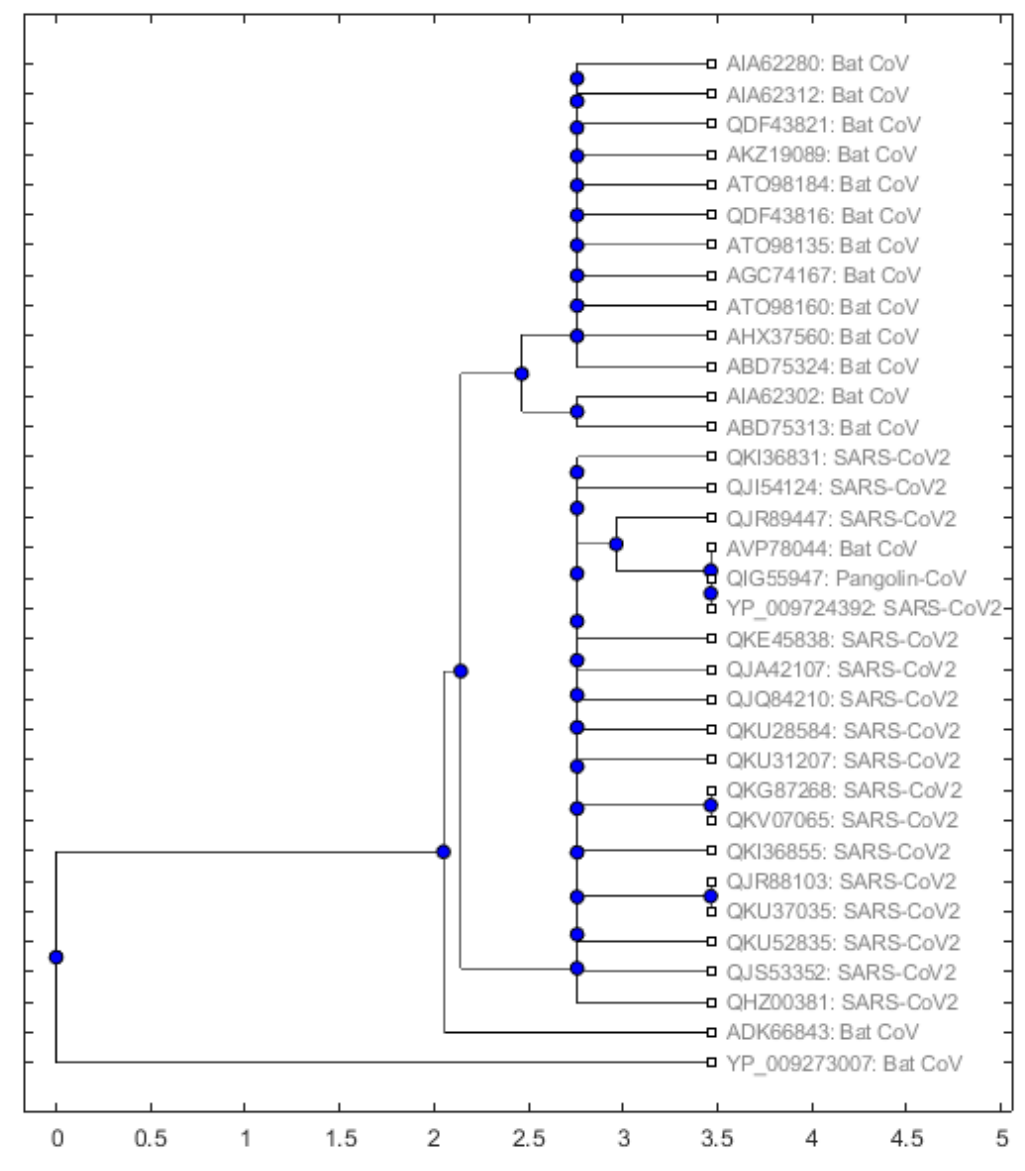

Figure 11: Phylogenetic relationship among envelope proteins of the SARS-CoV2, Bat and Pangolin CoVs with respect to the amino acids conservation

\section{Conclusions}

Here, we performed phylogenetic analysis using the protein sequences of coronaviruses from different hosts although different investigators also performed phylogenetic analysis using the genomic and protein sequences of few coronaviruses from different hosts [21]. But the phylogenetic analysis, using protein sequences from a large number of seuquences, may provide a better picture of the relationship among hosts so far as the intermediate host between human and bat is concerned since protein is the functional unit in the cell. So, this study, using protein sequence variations, may provide the clue why few hosts are resistant or sensitive to the disease Covid-19. We observed variations in protein sequences of E-protein in Human-SARS-CoV2, Bat-CoV, Camel-Cov etc. but no variation in protein sequence in Pangolin-CoV and Chimpanzee-CoV were obtained. Based on mutation characteristics and amino acid conservations over the E proteins across various host CoVs, this report predicts potential close kins of human SARSCoV2 as the Pangolin-CoV and Bat-CoV which was also reported in a recent study [21]. Pangolin, the closest kin of SARS-CoV2, is also confirmed by the analysis made in this study. The missense mutations of the E protein across various host CoVs, may bar the usual functions of the envelope protein and consequently the virus may become weaker in infectivity. It is our belief that various missense mutations in the E protein could weaken the SARS-CoV2 and would help us gets rid of COVID-19 in future. 


\section{Data Availability}

The protein sequences of the SARS-CoV2 and other host CoVs used in this study are available in the NCBI virus database https://www.ncbi.nlm.nih.gov/labs/virus/vssi/.

\section{Author Contributions}

SH conceived the problem. SH determined the mutations. SH, PPC, BR analysed the data and result. SH wrote the initial draft which was checked and edited by all other authors to generate the final version.

\section{Conflict of Interests}

The authors do not have any conflicts of interest to declare.

\section{References}

[1] E. G. Favalli, F. Ingegnoli, O. De Lucia, G. Cincinelli, R. Cimaz, R. Caporali, Covid-19 infection and rheumatoid arthritis: Faraway, so close!, Autoimmunity reviews (2020) 102523.

[2] M. Bartlam, H. Yang, Z. Rao, Structural insights into sars coronavirus proteins, Current opinion in structural biology 15 (6) (2005) 664-672.

[3] Y. Liao, Q. Yuan, J. Torres, J. Tam, D. Liu, Biochemical and functional characterization of the membrane association and membrane permeabilizing activity of the severe acute respiratory syndrome coronavirus envelope protein, Virology 349 (2) (2006) 264-275.

[4] J. L. Nieto-Torres, M. L. DeDiego, E. Álvarez, J. M. Jiménez-Guardeño, J. A. Regla-Nava, M. Llorente, L. Kremer, S. Shuo, L. Enjuanes, Subcellular location and topology of severe acute respiratory syndrome coronavirus envelope protein, Virology 415 (2) (2011) 69-82.

[5] J. L. Nieto-Torres, M. L. DeDiego, C. Verdia-Baguena, J. M. Jimenez-Guardeno, J. A. Regla-Nava, R. FernandezDelgado, C. Castano-Rodriguez, A. Alcaraz, J. Torres, V. M. Aguilella, et al., Severe acute respiratory syndrome coronavirus envelope protein ion channel activity promotes virus fitness and pathogenesis, PLoS pathogens 10 (5) (2014).

[6] L. Wilson, C. Mckinlay, P. Gage, G. Ewart, Sars coronavirus e protein forms cation-selective ion channels, Virology 330 (1) (2004) 322-331.

[7] K. Parthasarathy, L. Ng, X. Lin, D. X. Liu, K. Pervushin, X. Gong, J. Torres, Structural flexibility of the pentameric sars coronavirus envelope protein ion channel, Biophysical journal 95 (6) (2008) L39-L41.

[8] J. To, W. Surya, T. S. Fung, Y. Li, C. Verdia-Baguena, M. Queralt-Martin, V. M. Aguilella, D. X. Liu, J. Torres, Channel-inactivating mutations and their revertant mutants in the envelope protein of infectious bronchitis virus, Journal of virology 91 (5) (2017) e02158-16. 
[9] J. Han, K. Pluhackova, R. A. Böckmann, Exploring the formation and the structure of synaptobrevin oligomers in a model membrane, Biophysical journal 110 (9) (2016) 2004-2015.

[10] L. A. Lopez, A. J. Riffle, S. L. Pike, D. Gardner, B. G. Hogue, Importance of conserved cysteine residues in the coronavirus envelope protein, Journal of virology 82 (6) (2008) 3000-3010.

[11] B. Horwitz, A. Burkhardt, R. Schlegel, D. DiMaio, 44-amino-acid e5 transforming protein of bovine papillomavirus requires a hydrophobic core and specific carboxyl-terminal amino acids., Molecular and Cellular Biology 8 (10) (1988) 4071-4078.

[12] C. Yang, C. P. Spies, R. W. Compans, The human and simian immunodeficiency virus envelope glycoprotein transmembrane subunits are palmitoylated, Proceedings of the National Academy of Sciences 92 (21) (1995) 9871-9875.

[13] Y. Liao, J. Lescar, J. Tam, D. Liu, Expression of sars-coronavirus envelope protein in escherichia coli cells alters membrane permeability, Biochemical and biophysical research communications 325 (1) (2004) 374-380.

[14] K.-T. Teoh, Y.-L. Siu, W.-L. Chan, M. A. Schlüter, C.-J. Liu, J. M. Peiris, R. Bruzzone, B. Margolis, B. Nal, The sars coronavirus e protein interacts with pals1 and alters tight junction formation and epithelial morphogenesis, Molecular biology of the cell 21 (22) (2010) 3838-3852.

[15] Z. Zhao, H. Li, X. Wu, Y. Zhong, K. Zhang, Y.-P. Zhang, E. Boerwinkle, Y.-X. Fu, Moderate mutation rate in the sars coronavirus genome and its implications, BMC evolutionary biology 4 (1) (2004) 21.

[16] S. S. Hassan, P. P. Choudhury, P. Basu, S. S. Jana, Molecular conservation and differential mutation on orf3a gene in indian sars-cov2 genomes, Genomics 112 (5) (2020) 3226-3237.

[17] S. S. Hassan, P. P. Choudhury, B. Roy, Rare mutations in the accessory proteins orf6, orf7b and orf10 of the sars-cov2 genomes (2020).

[18] K. G. Andersen, A. Rambaut, W. I. Lipkin, E. C. Holmes, R. F. Garry, The proximal origin of sars-cov-2, Nature medicine 26 (4) (2020) 450-452.

[19] Y.-Z. Zhang, E. C. Holmes, A genomic perspective on the origin and emergence of sars-cov-2, Cell (2020).

[20] T. Zhang, Q. Wu, Z. Zhang, Probable pangolin origin of sars-cov-2 associated with the covid-19 outbreak, Current Biology (2020).

[21] P. Liu, J.-Z. Jiang, X.-F. Wan, Y. Hua, L. Li, J. Zhou, X. Wang, F. Hou, J. Chen, J. Zou, et al., Are pangolins the intermediate host of the 2019 novel coronavirus (sars-cov-2)?, PLoS Pathogens 16 (5) (2020) e1008421.

[22] The Mathworks, Inc., Natick, Massachusetts, MATLAB version (R2020a) (2020).

[23] F. Johansson, H. Toh, Relative von neumann entropy for evaluating amino acid conservation, Journal of bioinformatics and computational biology 8 (05) (2010) 809-823. 
[24] E. Garriga, P. Di Tommaso, C. Magis, I. Erb, L. Mansouri, A. Baltzis, H. Laayouni, F. Kondrashov, E. Floden, C. Notredame, Large multiple sequence alignments with a root-to-leaf regressive method, Nature biotechnology 37 (12) (2019) 1466-1470.

[25] F. Madeira, Y. M. Park, J. Lee, N. Buso, T. Gur, N. Madhusoodanan, P. Basutkar, A. R. Tivey, S. C. Potter, R. D. Finn, et al., The embl-ebi search and sequence analysis tools apis in 2019, Nucleic acids research 47 (W1) (2019) W636-W641.

[26] J. Weako, A. Gursoy, O. Keskin, Mutational effects on protein-protein interactions, Protein Interactions: Computational Methods, Analysis And Applications (2020) 109.

[27] D. Schoeman, B. C. Fielding, Coronavirus envelope protein: current knowledge, Virology journal 16 (1) (2019) 69.

[28] M. K. Gupta, S. Vemula, R. Donde, G. Gouda, L. Behera, R. Vadde, In-silico approaches to detect inhibitors of the human severe acute respiratory syndrome coronavirus envelope protein ion channel, Journal of Biomolecular Structure and Dynamics (2020) 1-11.

[29] J. W. Westerbeck, C. E. Machamer, The infectious bronchitis coronavirus envelope protein alters golgi ph to protect the spike protein and promote the release of infectious virus, Journal of virology 93 (11) (2019) e0001519.

[30] F. De Maio, E. L. Cascio, G. Babini, M. Sali, S. Della Longa, B. Tilocca, P. Roncada, A. Arcovito, M. Sanguinetti, G. Scambia, et al., Enhanced binding of sars-cov-2 envelope protein to tight junction-associated pals1 could play a key role in covid-19 pathogenesis (2020).

[31] S. S. Hassan, P. P. Choudhury, B. Roy, Sars-cov2 envelope protein: non-synonymous mutations and its consequences (2020). 